\title{
DANIELA MACHADO SECIOSO
}


RIO DE JANEIRO - BRASIL

\section{PUC}

DEPARTAMENTO DE DIREITO

REVISTA ÍNTIMA:

OS LIMITES DO PODER DIRETIVO

por

DANIELA MACHADO SECIOSO

ORIENTADOR(A): João Batista

2010.1

PONTIFÍCIA UNIVERSIDADE CATÓLICA DO RIO DE JANEIRO

RUA MARQUÊS DE SÃO VICENTE, 225 - CEP 22453-900 


\title{
REVISTA ÍNTIMA: \\ OS LIMITES DO PODER DIRETIVO
}

por

DANIELA MACHADO SECIOSO

\author{
Monografia apresentada ao \\ Departamento de Direito da \\ Pontificia Universidade Católica \\ do Rio de Janeiro (PUC-Rio) para \\ a obtenção do Título de Bacharel \\ em Direito.
}

Orientador(a): João Batista

2010.1 
DEDICATÓRIA

Aos meus pais, pelo incentivo, apoio e oportunidade.

À minha irmã, pelo carinho.

Aos meus amigos, pela amizade. 


\section{AGRADECIMENTOS}

À minha família pela benevolência, afeição, incentivo e apoio recebidos durante todo o curso;

Ao meu namorado, pelo amor e solidariedade;

Aos meus grandes e queridos amigos;

À todos os companheiros que me estimularam a enfrentar os desafios acadêmicos me fazendo chegar ao final do curso;

À PUC-RJ, pelo ensino de nobreza oferecido;

Ao Departamento de Direito e seu corpo docente, pela ajuda prestada durante o período em que estive na PUC-RJ;

Ao meu competente orientador, João Batista, cuja sabedoria, experiência e conhecimentos contribuíram para o desenvolvimento deste projeto. 


\section{RESUMO}

O presente trabalho tem como objetivo estabelecer os limites do poder diretivo do empregador e do direito à intimidade do empregado, nas diversas peculiaridades que envolvem o tema da revista íntima. Dessa forma, para se chegar a um posicionamento, farar-se-á um estudo jurisprudencial, das legislações aplicáveis ao tema e das discussões doutrinárias existentes. A atualidade e iminência do assunto no mundo jurídico, a inexistência de informações acerca da revista íntima e o aumento dessa prática como meio de fiscalização nas empresas foram os aspectos que levaram à feitura deste trabalho.

As palavras chaves são: Direito à Intimidade, Poder Diretivo do Empregador e Revista Íntima. 


\section{ABSTRACT}

This study aims to establish the limits of power to direct the employer and the employee's right to privacy, in many peculiarities around the topic, intimate magazine. So, to arrive at a position, it will make a study of case law, the laws applicable to the topic and the existing doctrinal discussions. The timeliness and imminence of the issue in the legal world, the lack of information about the intimate magazine and the increase in the practice as a means of control in companies, were the aspects that led to making this work.

The key words are: Right to Privacy, Power Steering Employer and Intimate Magazine 


\section{SUMÁRIO}

INTRODUÇÃO 7

CAPÍTULO 1 - Direito à intimidade ..........................................................

CAPÍTULO 2 - Poder diretivo do empregador .........................................18

CAPÍTULO 3 - Direito à intimidade X poder diretivo do empregador .....27

CAPÍTULO 4 - Revista íntima ..................................................................35

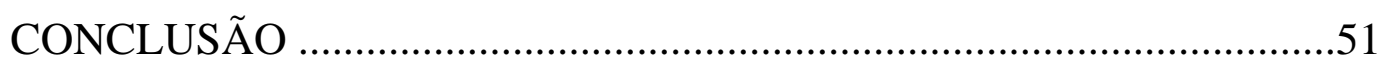

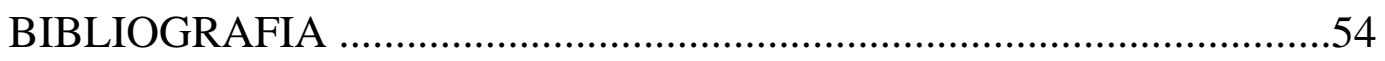




\section{INTRODUÇÃO}

O presente trabalho investiga a tensão entre o princípio constitucional da intimidade "versus" o poder diretivo do empregador. Nesse sentido, devemos apontar relevantes aspectos para que o leitor não fique perdido na referida tensão, bem como na análise da admissibilidade da revista íntima, tema que se passa a analisar.

Sendo o homem um ser social, é na própria sociedade que encontra razão para sua existência e desenvolvimento de suas capacidades e potencialidades. Como tal, possui vários papéis a serem exercidos, uma vez que são pressupostas as relações intersubjetivas. Relações essas exercidas como pai, mãe, filho, político, esportista e como empregado em inúmeras profissões. Não obstante, o homem, além dessa parte externa aos seus semelhantes, possui também uma outra parte que pode reservar das outras pessoas com quem mantém contato, bem como daquelas que não conhece. É nesse âmbito que o homem necessita e tem o direito de reservar-se à sua intimidade, para poder refletir sobre sua existência, entre outras coisas.

Dessa forma, o direito à intimidade é condição necessária ao ser humano que se preocupa com a evolução de seu interior. Além disso, é o último reduto da resistência do indivíduo às forças econômicas, políticas e culturais, que operam no sentido de seu aniquilamento e desequilíbrio. Sendo assim, mostra-se importantíssima a preservação de um mínimo de privacidade e intimidade para o desenvolvimento do homem, uma vez que devido ao progresso tecnológico e cientifico, inúmeras formas de violação à intimidade surgem a todo instante.

A discussão do tema sob enfoque apresentado neste estudo ainda é bastante incipiente no Brasil, sendo essa a principal razão de seu debate, uma vez que o tema a ser abordado, o direito à intimidade, é normalmente contrastado a um outro direito fundamental que é o do empregador de proteger o seu patrimônio. Neste trabalho, evidencia-se, particularmente, o 
direito à intimidade da pessoa do empregado frente ao empregador e seu poder de comando.

Além do que já se mencionou a respeito do tema, vale salientar que o presente trabalho visa abordar o recente conflito entre empregados e empregadores, cada qual na tentativa de tutelar seus direitos. Daqueles o direito à intimidade e dos últimos o poder de comando, de onde faz surgir a dúvida sobre quais são seus limites, a legislação existente, qual o posicionamento da doutrina e da jurisprudência a respeito.

Sendo assim, a proposta é, através de uma análise jurisprudencial, obter um posicionamento com relação aos limites do poder diretivo do empregador face ao direito à intimidade do empregado, nas diversas peculiaridades que envolvem o tema, qual seja, o da revista íntima. Para tanto, farar-se-á um estudo das legislações aplicáveis ao tema e das discussões jurisprudenciais existentes.

A razão para a escolha deste tema é a atualidade e iminência do assunto no mundo jurídico e a inexistência de informações acerca da revista íntima de forma sistematizada e didática. Contribui, nesse sentido, para a sociedade, por ser esta o público alvo da presente pesquisa. Assim, a revista íntima é uma realidade fática e jurídica, que vem sendo utilizada pelas empresas cada vez mais; porém, precisa ser regulada e especificada para que não seja violado o princípio da dignidade da pessoa humana, constitucionalmente consagrado.

O método é a forma escolhida para se expor a tese, o que, no caso em análise, se deu através de um estudo de casos combinado com uma análise jurisprudencial crítica. É um método lógico que analisa a jurisprudência e a doutrina atuais, partindo para a verificação dos pressupostos utilizados como ponderação entre o poder diretivo do empregador e o direito à intimidade do empregado e a sua compatibilização com o ordenamento jurídico brasileiro, resolvendo assim a problemática que envolve o tema. 
Quanto à técnica, o presente trabalho se utilizou de pesquisa bibliográfica, por meio de livros, legislações nacionais, jurisprudência e artigos obtidos na internet.

O projeto foi divido em quatro capítulos redigidos de forma dissertativa. No primeiro capítulo, tratou-se do direito à intimidade, abordando seu aspecto histórico, conceituação, pressupostos e requisitos, bem como o arcabouço principiológico que o cerca.

No segundo capítulo, foi abordado o poder diretivo do empregador, seus limites, conceituação, pressupostos e requisitos.

No terceiro capítulo, levantou-se a discussão com relação ao conflito entre o direito à intimidade e o poder diretivo do empregador, os métodos de solução de conflito e os parâmetros que envolvem o tema.

O quarto e último capítulo trata especificamente da revista íntima, com todas as suas especificidades, principalmente quanto à admissibilidade de tal conduta dentro das empresas, assim, a presente monografia com uma análise jurisprudencial verifica o entendimento que vem sendo adotado e faz um exame crítico de cada caso, concluindo ao final com relação à possibilidade ou não da revista íntima. 
O conhecimento histórico, em relação à intimidade, se tornou mais fácil após o processo contínuo e lento de passagem do gregarismo ao individualismo, com tendências à interiorização e à introspecção. Aristóteles, já naquela época, explicava que "a comunidade não é feita de iguais, mas ao contrário, de pessoas que são diferentes e desiguais”.1 A concepção aristotélica permitiu, anos depois, que a necessidade de tutelar as esferas da intimidade do “eu” e do "outro" fosse justificada pela ética do respeito e da tolerância.

A discussão a respeito do Direito à Intimidade iniciou-se em 1890 nos Estados Unidos, com a finalidade de dificultar a intromissão da imprensa na vida e na honra das pessoas. Assim, passou-se a entender que o direito à intimidade consistiria "no direito de ser deixado só".

No Brasil, o Direito à Intimidade só passou a fazer parte do ordenamento jurídico com a Constituição Federal de 1988, que ao dispor a respeito da tutela da intimidade do indivíduo, teve como base a Declaração Universal dos Direitos do Homem que determina em seu artigo XII que "ninguém será sujeito a interferências na sua vida privada, na família, no seu lar ou em sua correspondência, nem a ataques à sua honra e reputação. Todo homem tem o direito à proteção de lei contra tais interferências ou ataques”, bem como o Pacto de São José da Costa Rica, de 1969, que assegura que "ninguém pode ser objeto de ingerências arbitrárias ou abusivas em sua vida privada, na sua família, em seu domicílio ou em sua correspondência nem de ofensas ilegais à sua honra e reputação.”.2

No entanto, vale mencionar que no passado constitucional brasileiro já havia mecanismos normativos de proteção à privacidade e à intimidade

1 AIETA, Vânia Siciliano. A Garantia da Intimidade como Direito Fundamental. Editora Lumen Juris, 1999. p. 7. 
inseridos em outros direitos e valores constitucionais. Dessa forma, as Constituições anteriores consagraram, indiretamente, o direito à privacidade e à intimidade.

No âmbito internacional, cabe mencionar que vários instrumentos foram assinados com a finalidade de resguardar os direitos da personalidade, entre os quais está o Direito à Intimidade. Dentre os instrumentos assinados, apenas a título exemplificativo, vale lembrar a Convenção Européia dos Direitos do Homem (1950), o Pacto das Nações Unidas sobre Direitos Civis e Políticos (1966) e a Conferência Nórdica sobre o Direito à Intimidade (1967), todos visando corroborar a garantia ao Direito à Intimidade.

A internacionalização dos direitos da personalidade ocorreu em uma era em que se tornou mais visível a preocupação com a ética dos princípios. Um marco da internacionalização foi a Declaração Universal dos Direitos do Homem, de 1948, que já previa que "todos os homens nascem livres e iguais em dignidade e em direitos”. Em seguida, a Declaração prevê direitos ligados à pessoa humana (artigos 5 a 14): direito à vida, à liberdade, à segurança, à personalidade jurídica, à proteção jurisprudencial, de acordo com os princípios básicos do Direito Criminal, à igualdade perante a Lei, à inviolabilidade do domicílio e correspondência (como elos do direito à intimidade). 3

Hoje, após o árduo caminho de construção e positivação dos direitos fundamentais, o Direito reconhece os atributos da personalidade, com um sentido de universalidade, sendo a personalidade identificada como um atributo jurídico.

O direito à intimidade nasce como subespécie dos direitos da personalidade, sendo um direito de natureza moral, que provém da liberdade. É o direito de alguém recolher-se à solidão e ter seu universo intimo preservado, pois nada mais é, segundo o professor Pontes de 
Miranda que "um efeito do exercício da própria liberdade”, consistindo em fazer, ou deixar de fazer, o que melhor lhe prouver.4

Personalidade em sentido jurídico vem sendo entendida como a aptidão para ser sujeito de direitos e obrigações no mundo jurídico, toda pessoa humana tem essa aptidão, tratando-se de um dom inato. Sendo assim, de nada valeria o reconhecimento da condição de pessoa sem a outorga de um mínimo de direitos.

Vale mencionar que, alguns doutrinadores preferem falar direito à Vida Privada, enquanto outros, direito à Privacidade. Nesse sentido, interessante é explicar a teoria dos círculos concêntricos de René Ariel Dotii, que assevera que a Intimidade está inserida na Vida Privada como se fossem dois círculos, a Intimidade seria um círculo concêntrico e de menor raio que a Vida Privada. Quanto maior for a proximidade das informações a revelar das esferas de intimidade e segredo, maior peso terão que assumir as razões para a sua revelação, do ponto de vista do interesse público. No mesmo sentido assegura Darcy Arruda Miranda ao propor que devem ser considerados como pertencentes à Vida Privada da pessoa, “não só os fatos da vida íntima, como todos aqueles em que seja nenhum o interesse da sociedade de que faz parte". 5 Sendo assim, a intimidade seria uma espécie do gênero Privacidade, em que aquela só pode ser revelada ou violada se houver legítimo e autentico interesse público.

Dessa forma, dentre as garantias fundamentais do indivíduo, albergadas constitucionalmente no art. $5^{\circ}$, da Magna Carta, encontram-se positivados os direitos à intimidade e à vida privada, os quais, como direitos da personalidade, podem ser vislumbrados como elementos da integridade moral de cada ser humano. O artigo $5^{\circ}$, inciso X, da Constituição Federal prevê especificamente o direito à intimidade, in verbis:

4 AIETA, Vânia Siciliano. A Garantia da Intimidade como Direito Fundamental. Editora Lumen Juris, 1999. p. 90-91.

5 MARQUES, Andréa Neves Gonzaga. Artigo: Direito à intimidade e privacidade. Revista Jus Vigilantibus, Sabado, 23 de fevereiro de 2008 
Art. $5^{\circ}$ - Todos são iguais perante a lei, sem distinção de qualquer natureza, garantindo-se aos brasileiros e aos estrangeiros residentes no País a

inviolabilidade do direito à vida, à liberdade, à igualdade, à segurança e à

propriedade, nos termos seguintes:

$(\ldots)$

X - são invioláveis a intimidade, a vida privada, a honra e a imagem das pessoas, assegurado o direito a indenização pelo dano material ou moral decorrente de sua violação;

(...)

Diante da importância do que venha a ser intimidade, se faz necessário diferenciar intimidade e privacidade, mesmo não havendo na legislação pátria um conceito definido de tais institutos. A intimidade é um instituto mais restrito do que a privacidade. Nesse sentido, pode-se destacar a diferenciação feita por Cláudio de Castro Braz:

\begin{abstract}
em um esforço de impedir a fácil confusão entre intimidade e privacidade pode-se ter em conta que, enquanto aquilo que pertence ao indivíduo fica como relação consigo mesmo será parte de sua intimidade, onde se rejeita qualquer interferência. No entanto, quando esta porção interior passa a ser dividida exclusivamente com pessoas de seu núcleo restrito, quer familiar, quer de amizade íntima, torna-se parte de sua privacidade, ambos com a característica comum do desejo do não conhecimento público. 6
\end{abstract}

A intimidade consiste na esfera mais íntima do indivíduo, que está alheia a qualquer tipo de interferência, já a privacidade, possui uma abrangência um pouco maior, consistindo na esfera pessoal que o indivíduo compartilha com familiares e amigos próximos, não sendo, todavia, algo totalmente público.

No tocante ao direito à intimidade, cumpre aduzir que o mesmo revela a esfera recôndita do indivíduo, sendo o direito à liberdade pessoal de se manter isolado ou recolhido dentro do seu íntimo e da própria sociedade, o que implica afirmar que a esfera íntima do ser humano deve ser um mundo desconhecido das demais pessoas, a fim de que fique preservada a sua individualidade. 
A própria Constituição reconhece que a intimidade e a privacidade são institutos autônomos e que tutelam situações diversas, no entanto, ambos visam cumprir a finalidade traçada pelo constituinte originário de defesa da cidadania e do Estado Democrático de Direito.

Da inteligência da norma constitucional, é possível constatar que a vida privada se distingue da vida íntima, ou seja, aquilo que a pessoa pensa, sente e deseja se refere à sua intimidade. Já os seus hábitos (modo de viver, de se comportar), seu relacionamento e, igualmente, aquilo que o sujeito possui, têm pertinência com a sua vida privada.

Já há algum tempo, a doutrina vem conceituando o direito à intimidade como aquele que busca defender as pessoas dos olhares alheios e da interferência na sua esfera íntima, por meio de espionagem e divulgação de fatos obtidos ilicitamente. $\mathrm{O}$ fundamento de tal garantia estaria pautado no direito de fazer e de não fazer, que não deixa de ser o "direito de ser deixado em paz”, vale dizer, de não ser importunado pela curiosidade ou pela indiscrição alheia.

No âmbito civilista, o direito à privacidade é tipificado como direito da personalidade, inerente, pois, ao próprio homem, tendo por objetivo resguardar a dignidade e integridade da pessoa humana, sendo, ainda, caracterizado como um direito subjetivo absoluto, uma vez que exercitável e oponível erga omnes.

O atual Código Civil determina a proteção da vida privada no seu artigo 21, in verbis:

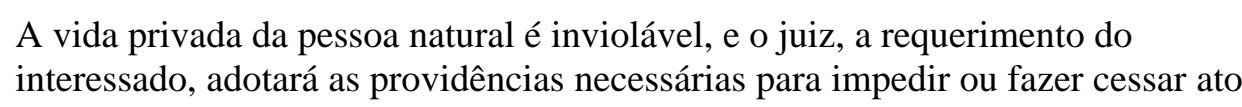

O ilustre doutrinador José Afonso da Silva em seu livro Curso de Direito Constitucional Positivo, atribui uma dimensão maior ao direito à privacidade, de modo a fazer nele compreender todas as manifestações da esfera íntima, privada, e da personalidade. No entendimento do professor 
José Afonso da Silva, a intimidade integra a esfera íntima da pessoa, os seus pensamentos, desejos e convicções, enquanto a vida privada significa o direito do indivíduo de ser e viver a própria vida, relacionando-se com quem bem entender. Relata que a Carta Magna, ao proteger a vida privada, se refere à vida interior, "como conjunto do modo de ser e viver, como direito de o indivíduo viver a própria vida” e não à vida exterior, que envolve a pessoa nas relações sociais e nas atividades públicas.

Dessa forma, embora usualmente os conceitos de vida privada e da intimidade se confundam, eles são distintos. Após uma breve diferenciação, podemos concluir que o Direito à intimidade é "a esfera secreta do indivíduo” já a vida privada, por mais isolada que seja, é sempre um viver entre os outros, o que não significa que pode cair no domínio público.

O direito à intimidade apresenta algumas características próprias, quais sejam: generalidade, uma vez que todas as pessoas são dotadas desse direito; extrapatrimonialidade, por serem insuscetíveis de avaliação pecuniária; absolutismo, em razão da oponibilidade erga omnes; inalienabilidade; irrenunciabilidade (impossibilidade de eliminação pelo seu titular); imprescritibilidade; e intransmissibilidade "post mortem".7

Da generalidade, vale mencionar, que surgem 2 (duas) consequências: a vitaliciedade e a necessidade. A vitaliciedade advém do fato de que enquanto perdurar a vida, o ser humano possuirá personalidade, possuindo aptidão genérica para ser sujeito de direitos e contrair obrigações.

Um outro aspecto relevante e discutido é com relação à intransmissibilidade em razão da morte, a priori, a morte extingue a possibilidade de lesão da intimidade do indivíduo, no entanto, muitos doutrinadores acreditam que a intimidade do morto pode vir a ser violada. Em muitos casos, a divulgação de fatos da intimidade do indivíduo morto pode comprometer os sentimentos e interesses morais dos parentes e familiares. 
Maria Helena Diniz afirma que os direitos da personalidade, como o direito à intimidade, são absolutos, no sentido de apresentarem-se oponíveis erga omnes, implicando dever geral de abstenção. Esta autora menciona ainda, que são diretos ilimitados, pois não se extinguem pelo não-uso ou pela inércia na defesa.8

A intimidade e a vida privada são direitos da personalidade especificamente condizentes com o direito da integridade moral. São valores subjetivos, relacionados tanto com elementos intrínsecos do ser humano como com suas próprias qualidades e virtudes, razão pela qual se incluem no âmbito da integridade moral.

A proteção à intimidade e à vida privada deve ter como fundamento maior a proteção à dignidade da pessoa humana, que é uma garantia constitucional da qual emana toda e qualquer proteção ao indivíduo. A proteção à vida privada corresponde a um direito da personalidade que ganhou considerações particulares a partir dos grandes avanços da ciência e da tecnologia, em uma nova era, na qual o poder significa conhecimento.

Cabe lembrar, todavia, que apesar de não haver lei ordinária que proteja a intimidade e a vida privada de nodo extensivo, tais institutos estão tutelados, no sistema jurídico brasileiro, por meio da proteção contra danos morais, por ataques à dignidade da pessoa humana; tipos penais de injúria, calúnia e difamação; crime contra a inviolabilidade de domicílio; crimes contra a inviolabilidade de correspondência; crime contra a inviolabilidade dos segredos; crime de tortura; contravenção penal de perturbação da tranqüilidade; regramento da interceptação.

Atualmente, a cada dia, o direito à intimidade vem adquirindo maior relevo com a freqüente expansão das técnicas de comunicação e vigilância. O rádio, a televisão, os computadores e a internet deram origem a uma verdadeira revolução tecnológica, que impõe ao indivíduo uma coordenação automática e manipulada, independentemente de sua vontade. 
O direito à intimidade há de ser resguardado e respeitado como uma conquista relevante que deve prevalecer apesar de todo o avanço tecnológico, porquanto é cada vez mais difícil garanti-lo tanto no ambiente de trabalho, como no doméstico. No campo profissional, os executivos e presidentes de empresas visam justificar suas condutas violadoras da intimidade de seus empregados sob a ótica patrimonialista e capitalista, fazendo uso de qualquer meio de fiscalização e vigilância para resguardar seus interesses. 
Numa evolução histórica, primeiramente, podemos destacar a época da Antiguidade, em que o trabalhador era visto como coisa, sem qualquer tipo de direitos, posteriormente, veio a época Medieval, em que, embora o trabalhador ainda fosse visto como escravo, já era considerado pessoa e não mais coisa. Com o surgimento das máquinas, ocorreu uma grande mudança no trabalho humano, no entanto, a obediência aos patrões, agora donos de fábricas, continuou resignada até a Revolução Francesa, quando a grande massa de trabalhadores se voltou contra, principalmente, a opressão do mando desmedido e do jogo imposto.

Desde a Revolução Industrial, portanto, é possível identificar duas classes sociais: os possuidores de dinheiro e detentores dos meios de produção (capitalistas ou empresários) e os vendedores da força de trabalho (trabalhadores). Essas duas classes, embora permaneçam em constante embate até os dias atuais, necessitam uma da outra: o capitalista precisa do trabalhador para alcançar seu objetivo, o produto, e o trabalhador precisa do capitalista para obter os bens necessários à sua sobrevivência e de sua família.

A principal crítica que se faz ao capitalista consiste justamente ao tratamento dado ao trabalhador, visto apenas como força de trabalho, ou seja, mercadoria, o que resulta dois grandes problemas: a alienação, que retira do trabalho o ato humano; e a desigualdade de condições para contratar, já que o homem vende sua força de trabalho apenas para gerar riquezas privadas, gerando assim uma inferioridade do trabalhador em relação ao empresário, absoluto detentor do poder econômico.

Visando minimizar essa inferioridade e alcançar um mínimo de igualdade é que o Estado passou a ditar regras, surgindo posteriormente o direito do trabalho, de cunho nitidamente protecionista, regulando os direitos sociais dos trabalhadores. 
O contrato de trabalho, hoje, é visto como um negócio jurídico, pelo qual uma pessoa física se obriga a prestar serviços de forma contínua à outra pessoa ou entidade, mediante remuneração e sob orientação. Sendo assim, se entende que esse tipo de contrato se insere na área da autonomia privada (ato negocial), pertencente à categoria dos contratos de atividade (implica na obrigação de executar tarefa, intuitu personae), pressupõe continuidade, subordinação (sujeição do trabalhador ao poder de direção do empregador), designa atividade por conta alheia (a prestação de serviço é para outrem) e requer retribuição (pagamento de salário).

Dessa forma, cabe ressaltar que por ser um trabalho livre a atribuição originária dos frutos a outra pessoa acontece por ato de vontade do trabalhador, estando esta liberdade intrinsecamente relacionada à dignidade da pessoa humana. Para tanto, assim como a dignidade do indivíduo que trabalha, o fator tempo, lugar e subordinação são de fundamental importância para a compreensão desse tipo de liberdade.

O tempo tem sua relevância pelo fato de que não se pode admitir que um trabalhador estabeleça uma relação com outrem eternamente, ou seja, não é admissível que o trabalhador venda sua liberdade, aceitando prestar serviço por toda a sua vida, estaria dando-se em propriedade a outra pessoa. O fator lugar também é fundamental na compreensão da liberdade que permeia o contrato de trabalho. É imprescindível que o empregado tenha a possibilidade de ir e vir.

Já o fator subordinação é conseqüência da prestação de serviço por conta alheia, que envolve uma relação de "sujeição" por parte do trabalhador às determinações do adquirente dos frutos, tendo como fundamento o poder diretivo do empregador.

Atualmente, se admiti o poder de comando do empregador dentro de uma relação de emprego, uma vez que ele se faz necessário frente às responsabilidades que possui o empregador, de gerir, coordenar, fiscalizar o empreendimento, sob pena de, não o fazendo, arcar com todos os riscos pertinentes, tanto a nível econômico-financeiro, quanto administrativo e 
fiscal. Pelo fato de ser o devedor da contraprestação salarial, credor da prestação de trabalho e de sua utilidade, é a figura central da empresa, no seu dinamismo econômico, social e disciplinar.

Dessa forma, ao se admiti o poder de comando e considerá-lo legítimo, é fundamental verificar a sua origem, que advêm da época em que o trabalho era tarefa de escravo. Hoje, se encontra na doutrina majoritária 2 (duas) posições fundamentais quanto à natureza jurídica do poder diretivo. Uma teoria é a contratualista, que se baseia na idéia de acordo de vontades entre as partes, em torno da qual há o desenvolvimento das relações entre empregado e empregador, inclusive as que geram o conceito de subordinação e de poder diretivo. A parte da doutrina que adota essa teoria se divide em duas correntes: a unitária e a dualista. A primeira defende que o contrato de trabalho constitui a fonte das obrigações nele contidas e também das que surgem em sua vigência, pela ação do poder diretivo do empregador. Já os dualistas defendem que o contrato de trabalho contém apenas as obrigações nele pactuadas e que as surgidas durante sua vigência provêm de outra fonte, a qual chamam de poder diretivo.9

Pelo explicitado, pode-se concluir que para os dualistas o poder diretivo é um poder potestativo.

A segunda teoria é a institucional, que sustenta que a disciplina do trabalho desenvolvido na empresa não deriva do contrato e sim de sua organização interna. Sob essa ótica, há a pressuposição da colaboração entre empregadores e trabalhadores, com o propósito de realizar um fim socialmente útil, um objetivo comum, o que exige um ordenamento jurídico.10

Do mencionado até o momento, é possível verificar que o poder de comando é um conjunto de prerrogativas asseguradas pela ordem jurídica, ao empregador, para seu exercício em uma relação de emprego. Sendo, portanto, poder de comando a capacidade, oriunda do direito subjetivo do 
empregador ou da organização empresarial, de determinar a estrutura técnica e econômica da empresa e dar conteúdo concreto à atividade do trabalhador, visando a realização das finalidades daquela.11

Dessa forma, pode-se dizer que o poder de direção, diretivo ou de comando do empregador é a capacidade que ele possui de determinar a forma pela qual ocorrerá a prestação de serviços por parte do empregado.

Nos termos da Consolidação das leis do Trabalho, que estabelece em seu artigo $2^{\circ}$ que empregador é quem, além de assumir os riscos da atividade econômica (alteridade) e pagar salários aos trabalhadores, também dirige a prestação pessoal dos serviços. Assim, por imposição ética, o empregador deve exercer esse poder de direção em favor da "organização de trabalho alheio", em benefício da empresa, da comunidade de trabalho e do grupo social.

Art. $2^{\circ}$ - Considera-se empregador a empresa, individual ou coletiva, que, assumindo os riscos da atividade econômica, admite, assalaria e dirige a prestação pessoal de serviço.

No contrato de trabalho, pode-se observar a existência de 3 (três) tipos de poderes, que são: poder diretivo, poder hierárquico, poder de fiscalização e poder disciplinar.12

O poder diretivo consiste na existência da subordinação, onde há o exercício do poder de direção e comando do empregador. Dessa forma, é a partir do poder diretivo que as condições para utilização e aplicação concreta da força de trabalho do empregado são delineadas, segundo os limites previstos em contrato.13

A conotação moderna do poder diretivo consiste num poder jurídicos decorrentes do contrato de trabalho, pelo qual o trabalhador está obrigado a prestar serviços em regime de "colaboração subordinada". Num trabalho

111bid. p.94

12 SOUZA, Mauro Cesar Martins de.Texto: E-mail (... net) na relação de emprego: poder diretivo do empregador (segurança) \& privacidade do empregado; Matéria publicada em 01/11/2000 Edição Número 15 - site: www.kplus.com.br. 
que participem diversas pessoas é incontestável o dever do mesmo de ser organizado, orientado, coordenado segundo alguma idéia, direção ou plano de conjunto.

Com relação ao poder hierárquico, pode-se dizer que é a partir dele que o poder diretivo se manifesta, por meio da organização e com base na liberdade econômica e no direito de propriedade. Da hierárquica surge o poder de comando dos superiores sobre os inferiores e o dever de obediência dos inferiores com relação aos superiores. Para uns essa obediência se trata de colaboração, para outros é uma mera submissão à autoridade.14

O poder de fiscalização consiste no direito do empregador de verificar o cumprimento da prestação de trabalho, ou seja, verificar se a atividade está sendo exercida de acordo com as instruções fornecidas. A referida fiscalização pode se dá de forma genérica ou de forma concreta, verificando a assiduidade e pontualidade do trabalhador, consistindo assim na faculdade de o empregador de fiscalizar as atividades profissionais de seus empregados. O poder de controle dá ao empregador o direito de fiscalizar o trabalho, a forma de sua realização, assim como a utilização de material e ferramentas de trabalho.15

O poder disciplinar deriva do direito do empregador de aplicar sanções disciplinares aos empregados que cometem alguma infração em relação ao contrato de trabalho. Consiste na forma de auto-tutela de solução da lide, em que se busca garantir os próprios interesses. A desobediência às normas oriundas de regulamento, instruções, ordens de serviço e circulares, de forma genérica ou individual, formal ou verbal, podem ocasionar sanções, as quais devem ser proporcionais com relação à falta cometida. O exercício do poder diretivo não seria eficaz se o empregador não tivesse meios e poderes para penalizar o empregado nos casos em que esse não

15 SOUZA, Mauro Cesar Martins de.Texto: E-mail (... net) na relação de emprego: poder diretivo do empregador (segurança) \& privacidade do empregado; Matéria publicada em 01/11/2000 Edição Número 15 - site: www.kplus.com.br. 
cumpre seus deveres, sendo uma faculdade do patrão de reprimir o descumprimento das ordens geral ou específica ao empregado destinadas, a fim de tomar eficaz o poder diretivo.16

Nesse sentido, vale frisarmos o artigo 482, alíneas “b” e "h" da Consolidação das Leis do Trabalho, que menciona o dever de respeito, obediência e de comportamento inatacável por parte do empregado, in verbis:

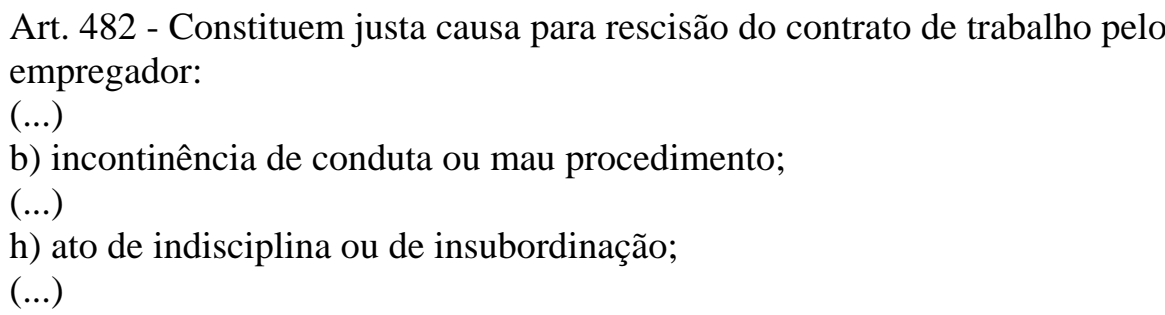

Vale mencionar ainda, que a legislação consolidada ratifica indiretamente $o$ poder disciplinar do empresário ao cuidar da suspensão disciplinar, que consiste no afastamento do serviço com a perda dos salários relativos aos dias de suspensão, conforme disposto no artigo 474 da CLT:

A suspensão do empregado por mais de 30 (trinta) dias consecutivos importa na rescisão injusta do contrato de trabalho

A aplicação das sanções, segundo a Doutrina, tem 3 (três) propósitos fundamentais: punitivo (punir a falta cometida); educativo (prevenir possíveis faltas futuras de um certo empregado); político (manter a ordem interna da empresa, resguardando o cumprimento das regras impostas).

Todavia, para que a punição tenha validade, é preciso que haja nexo causal e imediata aplicação da pena, ou seja, se faz necessário que a penalidade seja sempre conseqüência direta de uma certa e específica falta cometida. Além disso, outros requisitos devem ser atendidos, dentre os quais cabe destacar: proporcionalidade (decorre da razoabilidade e dos ideais de ética, justiça e equidade que a punição deva ser proporcional ao 
ato faltoso), imediatidade (atualidade - a falta deve ser punida tão logo seja conhecida), "non bis in idem" (não pode haver mais de uma punição para a mesma falta) e igualdade (faltas idênticas devem receber punições idênticas).

Por outro lado, existem limites ao poder diretivo do empregador, que não é absoluto, sendo o primeiro deles o respeito à dignidade da pessoa humana do trabalhador, o reconhecimento dos direitos do empregado enquanto Homem. O Princípio da Dignidade da Pessoa Humana está previsto na Constituição Federal, in verbis:

Art. $1^{\circ}$ - A República Federativa do Brasil, formada pela união indissolúvel dos Estados e Municípios e do Distrito Federal, constitui-se em Estado Democrático de Direito e tem como fundamentos:

(...)

III - a dignidade da pessoa humana

(...)

O poder diretivo do empregador, embora constitua fundamento

constitucional do exercício da atividade econômica e da própria República Federativa do Brasil (art. $1^{\circ}$, inc. III e art. 170, caput, da CF), também é inequívoca e eminentemente ético o dever de respeito à dignidade humana. O trabalhador não é "coisa", nem tampouco uma máquina que vende sua força de trabalho, mas um indivíduo dotado de poder criativo, vontade, sentimento, imaginação, preocupações, necessidades, objetivos, história e valores pessoais.

O bom funcionamento da máquina empresarial depende da peça essencial que é o Homem, a pessoa humana operária, o indivíduo que contribui para a organização compartilhando a manifestação singular de sua personalidade única, desta forma agregando valor, originalidade e qualidade ao meio produtivo em que atua.

Com efeito, pode-se observar que os limites básicos e intransponíveis ao poder diretivo empresarial advêm dos direitos fundamentais de qualquer ser humano, como o direito à vida, à liberdade, à segurança, à propriedade, à privacidade e à igualdade. Por conseguinte, será 
sempre ilegal e, obviamente, imoral: o trabalho escravo (por afronta ao princípio da liberdade); a contratação de trabalhadora para exercer a mesma função ocupada por empregado, mas ganhando salário menor (por violação ao princípio da igualdade ou isonomia); o trabalho em condições insalubres ou perigosas, sem treinamento adequado e sem o fornecimento dos equipamentos de proteção individual (por ofensa ao direito à segurança e à saúde); submeter o empregado a revista íntima e vexatória, sob a suspeita de prática de ato que atentaria contra o patrimônio da empresa (por agressão ao direito à intimidade), etc.17

Existem todavia, outros princípios e garantias constitucionais assegurados a todas as pessoas, mas que também protegem aquelas que integram as relações individuais e coletivas de trabalho, dentre os quais convém ressaltar os seguintes : legalidade ("ninguém é obrigado a fazer ou deixar de fazer alguma coisa senão em virtude de lei", princípio que se traduz, por exemplo, na ilicitude dos descontos salariais sem prévia estipulação legal, normativa ou contratual); liberdade de expressão, manifestação e comunicação, individual e coletiva; liberdade de reunião e de associação para fins lícitos; liberdade de consciência, convicção e crença religiosa, filosófica ou política; inviolabilidade da intimidade, vida privada, honra e imagem das pessoas; inviolabilidade da correspondência pessoal; etc.18

A boa-fé norteia todas as relações jurídicas, devendo, portanto, também estar presente na relação de emprego, sendo aplicada tanto ao empregado quanto ao empregador. Por ser um princípio ético e basilar deve ser respeitado nas relações privadas e servir como parâmetro para as limitações do poder diretivo.

Por último, cabe lembrar, que o empregador pode recusar-se a cumprir uma ordem que fuja da natureza do trabalho contratado, que lhe coloque em risco, cause humilhação, ou que seja ilícita, ilegal ou de

17 Direitos e garantias previstas na Consolidaç̃o das Leis do Trabalho e na Constituiç̃õo Federal.

18 Direitos e garantias contidos no artigo $5^{\circ}$ e incisos do Constituição Federal. 
execução difícil. Esse direito de recusa tem base no pressuposto legal da liberdade individual do trabalhador e de sua dignidade. 
DO DIREITO À INTIMIDADE X PODER DIRETIVO DO

EMPREGADOR

Por todo o já mencionado neste trabalho, pode-se verificar a impossibilidade de se conceber o homem trabalhador sem as devidas garantias aos seus direitos humanos e de personalidade. Não há como ocorrer a dissociação dos direitos constitucionais da personalidade, que asseguram a intimidade do indivíduo em suas relação sociais, com os demais ramos do direito, especificamente do direito do trabalho, sendo que, os direitos humanos clássicos individuais e os direitos sociais se completam, exercendo uma mútua influência.

Como se vê, o poder de direção não é absoluto, ao contrário, encontra limitação no rol das liberdades públicas, na dignidade da pessoa humana do trabalhador e no respeito à intimidade e vida privada do empregado. $\mathrm{O}$ estado de subordinação jurídica presente na relação de emprego não retira do empregado a garantia de seus direitos fundamentais, que nunca se dissociam do indivíduo, acompanhando-o em todas as relações.

Verifica-se daí que, o direito à intimidade, como subespécie dos direitos de personalidade, é ponto limitador da atuação do empregador, bem como atua no momento laborativo e de socialização dos empregados entre si.

Por outro lado, é inegável que o poder diretivo do empregador sobre os empregados, lhe permite traçar regras que mantenham a empresa funcionando sem prejuízo aos seus empregados, independentemente do empregado sob sua autoridade. A empresa tem o direito, através de seu departamento técnico, de criar mecanismos de proteção ao seu patrimônio e às suas mercadorias, para tanto, hoje com o avanço tecnológico, existem diversos meios de prevenção e proteção, no entanto, muitos 
empreendimentos comerciais e/ou industriais preferem fazer uso de meios menos custosos, não se importando com a violação há intimidade e privacidade de seus funcionários.

Admiti-se que o direito a intimidade não é absoluto, como qualquer liberdade pública, todavia, isso não leva ao absolutismo do poder diretivo do empregador.

O poder de organização, decorrente do poder diretivo, permite que o empregador expeça regras para o andamento dos serviços na empresa. Dessa forma, o método mais utilizado pelo poder de organização é o conjunto de normas estruturais chamado Regulamento de Empresa, cujo teor obriga tanto os trabalhadores como o empregador.

Nos casos em que o princípio da intimidade do empregado pode ser afetado, por parte dos empregadores, haverá sempre a necessidade de regulamentação do caso hipotético, em regulamento de empresa, para a não constatação de surpresa e alegação de falta de ciência do empregado.

Entretanto, nesses casos, muitas vezes, as empresas utilizam da legitimidade da prática do ato de dispensa por justa causa, face a ciência prévia do empregado, para abusar do direito do poder diretivo e fazer uso da revista íntima de forma desenfreada.

Em suma, embora tenha o empregador o direito de resguardar/proteger seu patrimônio, não está por isso autorizado a agir de modo a magoar o direito à intimidade de seus empregados, agredindo, impiedosamente, a dignidade de pessoa humana que todos têm, e não a possui menos uma pessoa por ser empregada, procedendo a revistas íntimas em qualquer caso e de modo constrangedor.

Portanto, a proteção civil do direito à honra, à intimidade pessoal e familiar e a própria imagem não poderá ser rompida por intromissões ilegítimas. O exercício do poder diretivo e fiscalizador do empregador não podem servir em nenhum momento para a produção de resultados inconstitucionais, lesivos dos direitos fundamentais do trabalhador. Nos casos em que surjam conflitos aonde haja direitos fundamentais em questão, 
como o direito à intimidade, deve ser ponderado, mediante a aplicação do princípio da proporcionalidade, como medida de respeito ao direito.

Aplicando este princípio será possível conciliar direitos sem que os mesmos tenham o condão de lesionar garantias previstas quando forem confrontados.

Assim como já exposto, o sistema jurídico é composto de diversos princípios e direitos fundamentais, que se complementam e formam uma unidade. Os princípios, assim como os direitos fundamentais, da constituição, não se contrariam, pois senão enquanto sistema aberto seria admitir, que esse sistema conteria uma desarmonia entre seus elementos. No entanto, na aplicação dos princípios ou dos direitos fundamentais no caso concreto, pode haver uma contradição entre dois ou mais princípios/direitos.

Quando direitos fundamentais colidem, um deles tem que ceder em relação ao outro, porém isto não significa declarar inválido o direito afastado. O que sucede, mais exatamente é que, sob certas circunstâncias, um dos direitos precede o outro. Os conflitos de regras resolvem-se na dimensão da validade; a colisão de princípios e direitos fundamentais válidos tem lugar para além da dimensão da validade, na dimensão do peso.

Há uma ponderação entre os princípios e não a opção pela aplicação de um deles, em detrimento do outro. Já com as regras jurídicas, quando duas delas aparentemente incidem sobre determinada hipótese fática, a questão é resolvida através do recurso aos critérios hierárquico, cronológico e de especialidade - ou, eventualmente, as regras de conexão do Direito Internacional Privado sobre o conflito de leis no espaço -, que acarretam a opção por uma das regras, com a completa desconsideração da outra.

Nesse sentido, o jurista Paulo Bonavides, leciona: “...o princípio cuja a aplicabilidade ao caso concreto se viu recusada por ensejo da ponderação estimativa de valores, bens e interesses levados a cabo pelo intérprete, 
continua a circular válido na corrente normativa do sistema, conservando intacta a possibilidade de aplicação futura”.19

Vale ressaltar, que não há hierarquia, a priori, entre os princípios, pois a prevalência de cada um deles na solução do problema jurídico dependerá das circunstâncias específicas do caso concreto. Nesta linha, pode-se dizer que os princípios são incompatíveis entre si, sendo sempre concorrentes, ao contrário do que se dá com as regras jurídicas.

Os princípios são deveres de otimização, o que provoca na aplicação uma colisão, cuja solução depende de uma ponderação, sendo que os dois princípios em tensão permanecem intactos para um futuro aproveitamento. Em sendo possível, deve-se buscar a solução que realize ambos. Assim, no momento da ponderação, o intérprete deve equilibrar e ordenar os bens conflitantes, elaborando critérios de ordenação, para que em relação ao caso concreto, se obtenha a solução justa. Da mesma forma, é solucionado o conflito entre direitos fundamentais, utilizando-se a ponderação.

Sendo assim, vale mencionar a função primordial da ponderação, nas palavras de Ana Paula de Barcellos: “O propósito da ponderação é solucionar esses conflitos normativos da maneira menos traumática para o sistema como um todo, de modo que as normas em oposição continuem a conviver, sem a negação de qualquer delas, ainda que em determinado caso concreto elas possam ser aplicadas em intensidades diferentes”.20

São três as fases da ponderação. Primeiramente, o aplicador identifica as normas veiculadoras de direitos fundamentais que estão em conflito. Depois, passa a examinar a situação fática e sua repercussão sobre as normas conflitantes. Na última fase, que é a da decisão, deve haver uma apreciação conjunta dos diferentes grupos de normas e a repercussão dos fatos sobre eles, com o desiderato de atribuir "pesos” aos diferentes 
elementos em colisão, determinando quais devem prevalecer e em que intensidade. Chega-se assim, a uma solução justa no caso concreto.

Para tanto, os princípios da harmonização ou concordância prática e da proporcionalidade são parâmetros importantes para se chegar a uma solução adequada ao caso concreto. O Princípio da harmonização determina a combinação dos princípios e/ou direitos em conflito, de modo a evitar o sacrifício total de uns em relação aos outros, impõe o estabelecimento, de limites e condicionamentos recíprocos, alcançando assim uma harmonização ou concordância prática entre eles e requer a contemplação da constituição como um todo, devendo-se preservar e concretizar ao máximo os direitos e bens constitucionais envolvidos. Os dois direitos fundamentais em conflito não devem ser visualizados isoladamente, mas em consonância com o conjunto, do qual são parte inseparáveis.

Já o princípio da proporcionalidade é usado como critério determinador do modo de incidência de cada princípio/direito. Este princípio contem 3 (três) subprincípios, que são: adequação, necessidade e proporcionalidade em sentido estrito. A adequação (aptidão ou pertinência) é um meio empregado para vedar o arbítrio, através da ponderação entre o meio empregado e o fim que se deve atingir. A necessidade impõe que a medida não exceda os limites indispensáveis à consecução do fim legítimo almejado. Deve-se lançar mão do menor esforço possível ou buscar o resultado menos gravoso dentre os prenunciados. O princípio da proporcionalidade em sentido estrito, também é denominado razoabilidade, exigibilidade ou de justa medida. Exige que haja uma ponderação da relação entre os danos causados por determinada medida e os resultados obtidos.

Assim, nas palavras de Daniel Sarmento o nível de restrição de cada interesse será inversamente proporcional ao peso específico que se emprestar, no caso, ao princípio do qual ele se deduzir, e diretamente 
proporcional ao peso que se atribuir ao princípio protetor do bem jurídico concorrente.21

A proporcionalidade é a forma de suavizar a aplicação pura e direta das normas constitucionais, sempre tendo em mente os valores envolvidos e a melhor maneira de otimizar sua aplicação, balizando a interpretação pela efetivação do interesse público, no mesmo momento em que se impede sacrifício aos direitos do indivíduo.

Com efeito, os direitos fundamentais representam as concretizações e exigências do princípio da dignidade da pessoa humana. Portanto, sempre que houver colisão entre eles, a interpretação deve se aproximar ao máximo da realização deste princípio fundamental, sempre tendo em vista a perspectiva de um Estado facilitador do exercício das liberdades, que atue com o fim último de enaltecer a figura do indivíduo como um ser dotado de dignidade e, portanto, sujeito - e não objeto - de direitos.

A dignidade da pessoa humana foi um marco essencial na superação do autoritarismo e na restauração do Estado Democrático de Direito, marcado pela preocupação com a promoção dos direitos humanos e da justiça social no país.22

Conceituar o princípio da dignidade da pessoa humana se mostra desnecessário, visto que se trata de uma idéia imanente à natureza humana. Somente no caso concreto, é possível vislumbrar os contornos da dignidade da pessoa humana de forma nítida, mas ainda assim, por uma perspectiva negativa. Tal ocorre quando o homem passa a ser desconsiderado como sujeito de direitos. 
Neste sentido, a dignidade é compreendida como atributo inalienável da pessoa humana, que não pode dela dispor em suas relações de ordem privada.

Sendo assim, toda atividade estatal deve desenrolar-se com total respeito à dignidade da pessoa humana, cabendo aos órgãos estatais abster-se de interferir na esfera individual e usar de todo o seu aparato para evitar que terceiros, mesmo que no uso de sua liberdade, afrontem a dignidade de qualquer dos cidadãos. Sendo, portanto, a dignidade humana fundamento basilar da ordem constitucional, na qualidade de vértice axiológico da Constituição, e diretriz inafastável para a interpretação de todo o ordenamento.

Por fim, cabe explicitar que o princípio da dignidade da pessoa humana também não é absoluto, tratando-se de mais um parâmetro a ser utilizado no exercício de ponderação, dotado de grande autoridade, mercê, principalmente, de seu status de princípio fundamental do Estado Democrático de Direito. Por esta razão deve sempre ser considerado para a solução de colisão de direitos fundamentais, sendo o ponto de apoio e a finalidade a ser alcançada.

Neste contexto, mostra-se relevante lembrar alguns limites plausíveis ao direito à intimidade e à vida privada, quais sejam: supremacia do interesse público, que é o interesse da Administração Pública, diretamente relacionada ao interesse efetivo da sociedade e com a segurança nacional; interesse histórico, que consiste no direito que tem a sociedade, presente e futura, de conhecer os acontecimentos que marcaram determinadas épocas; consentimento do titular, que não significa a transmissão a outrem, disposição, nem renúncia. O consentimento tem caráter temporal, valendo para situações determinadas e previamente estabelecidas.

Por todo o explicado, conclui-se que nem o direito à intimidade nem o direito ao poder diretivo deve ser absoluto e se sobrepujar a outros de mesmo nível hierárquico, devendo ceder ambos em sua aplicação quando for necessário para alcançar o fim último do direito. 
Portanto, não parece razoável, nem proporcional, que sob a justificativa de proteção do direito à propriedade e ao patrimônio, o empregador possa violar brutalmente a intimidade de seus funcionários, pessoas humana, exigindo-lhes que se submetam à revista íntima. Ao analisar o caso específico da Revista Íntima algumas questões precisam ser respondidas para que se efetive a ponderação, quais sejam: Seria necessária a violação do direito à intimidade para se atingir a finalidade de proteção do patrimônio da empresa? Seria o meio mais adequado? Estar-se-ia buscando, em última análise, o respeito ao princípio da dignidade da pessoa humana, ou se estaria violando-o?

Atualmente, em decorrência do desenvolvimento tecnológico diário, inúmeros métodos eficazes de proteção patrimonial surgem e são aprimorados, não sendo necessária, nem adequada a utilização de um método como a revista íntima, que viola o princípio basilar do Estado de Direito, a dignidade da pessoa humana. Assim, no conflito entre intimidade e poder diretivo do empregador, a razoabilidade nos leva para a conclusão de que o direito à intimidade deve prevalecer em detrimento do direito diretivo do empregador em proteger o seu patrimônio. 


\section{REVISTA ÍNTIMA}

Trata-se a revista íntima de meio pelo qual o empregador, como forma de proteger seu patrimônio, revista o empregado, de modo a lhe ferir o direito à intimidade. Dessa forma, qualquer espécie de revista que atinja a intimidade do empregado (homem ou mulher) pode ser considerada revista íntima.

Como exemplos de revista íntima, por curiosidade, valem mencionar casos em que o empregador determina que seus funcionários abaixem as calças, tirem a blusa ou, até mesmo, fiquem nus. Caracteriza-se a revista íntima o fato do empregador revistar bolsas, sacolas e armários individuais, bem como apalpar seus empregados, em busca de possíveis objetos furtados.

Obviamente, a revista íntima é vedada por lei. A Constituição Federal dispõe em seu art. $5^{\circ}$, X, ser inviolável a intimidade e a honra das pessoas, conforme foi mencionado no Capítulo que fala do Direito à Intimidade. Ademais, a Lei 9799/99 alterou a CLT (Consolidação das Leis do Trabalho) e incluiu o art. 373-A, que prevê ser vedado a revista íntima pelo empregador ou seus prepostos em seus funcionários.

\footnotetext{
Art. 373-A. Ressalvadas as disposições legais destinadas a corrigir as distorções que afetam o acesso da mulher ao mercado de trabalho e certas especificidades estabelecidas nos acordos trabalhistas, é vedado:

(...)

VI - proceder o empregador ou preposto a revistas íntimas nas empregadas ou funcionárias.
}

A Constituição de 1988 estabelece, dentre os direitos fundamentais, que a intimidade e a vida privada são "invioláveis" (art. $5^{\circ}$, inc. X), no entanto, a referida previsão genérica não atende as necessidades cotidianas atuais. A função da Constituição, no campo dos direitos civis, é estabelecer princípios genéricos, cabendo ao aplicador do direito (e ao legislador 
ordinário) interpretar a amplitude, os limites e adequar os princípios mencionados ao caso concreto, levando em conta, inclusive, todos os demais princípios constitucionais envolvidos. Assim, é preciso extrair do texto constitucional se revistar íntima ou a pertences de empregados viola a intimidade e a vida privada ou se esta conduta pode ser vista como um direito (igualmente constitucional) do empregador em proteger seu patrimônio.

Até pouco tempo, os tribunais trabalhistas vinham entendendo de forma conservadora, que revista sobre o empregado poderia ser feita desde que não fosse "vexatória". Este tipo de decisão, além do seu conservadorismo, transferia a dúvida de interpretação sobre o significado constitucional de "intimidade" para o significado jurisprudencial de "vexatória”.

Diante tais decisões, surgiram inúmeras teses com relação ao conceito de "vexatória”. A maioria dos juízes entendiam que a determinação para que o empregado se despisse diante de um superior seria “vexatória". Outros, dependendo da natureza da atividade empresarial (transporte de valores, por exemplo), admitiam inclusive o despir-se como não vexatório, desde que a revista fosse feita em ambiente restrito, por pessoa do mesmo sexo.

Dessa forma, por não haver unanimidade sobre o que seria vexatório ou não, começaram a surgir decisões divergentes para casos semelhantes. Na verdade, o conceito do que é vexatório varia muito de acordo com cada pessoa, visto que o tema em ênfase aborda aspectos íntimo-físicos e psicológicos do indivíduo. Vergonha e constrangimento são institutos literalmente pessoas.

Em 1999, tentou-se solucionar o problema mencionado no parágrafo anterior, visto que o legislador aprovou a Lei 9.799 que proíbe ao "empregador ou seu preposto de proceder a revistas íntimas nas empregadas ou funcionárias”. Porém, de antemão é preciso esclarecer que em função do princípio da isonomia, este dispositivo é aplicável indistintamente a homens 
e mulheres. A referência ao sexo feminino deveu-se ao fato de que a lei foi publicada para assegurar direitos específicos da mulher no mercado de trabalho.

Como é possível perceber através de uma interpretação literal, o novo texto da lei, embora aponte em certa direção, não ajudou muito, pois, afinal, "revista íntima” também não possui um conceito pré-definido e determinado. Assim, todo o debate anteriormente mencionado foi direcionado para o que seria “revista íntima”, permanecendo as inúmeras divergências jurisprudenciais.

Diante um cenário um tanto quanto inseguro juridicamente, é preciso ter em mente que o contrato de trabalho tem como um de seus elementos principais a confiança, não parecendo razoável que o empregador lance diariamente dúvidas sobre o caráter de seus empregados a pretexto de defender seu patrimônio. Outro aspecto um tanto curioso, consiste no fato de que em relação aos clientes ou consumidores, o empregador jamais se comportaria de tal modo, com os quais no mais das vezes não mantém vínculo contratual de confiança.

Muitos defensores da legalidade da revista feita aos empregados equiparam tal prática às revistas feitas pelas casas de espetáculo ou organizadores de eventos ao público. Todavia, é preciso perceber que a mencionada tese parte de uma premissa equivocada, já que pretende comparar duas situações jurídicas que, embora aparentem alguma semelhança (possibilidade de revista íntima), possuem pressupostos fáticos bem distintos. O responsável pela casa de espetáculos, por exemplo, ao promover a revista sobre os espectadores, tem como finalidade a garantia da segurança coletiva de todos. Ou seja, a perturbação da intimidade neste caso visa a preservar a garantia constitucional da vida e tem como destinatárias as próprias pessoas que são revistadas. Sob este ângulo, seria até mesmo possível admitir a revista em empregados se a finalidade fosse garantir sua segurança e incolumidade. No entanto, na maior parte dos casos, o 
empregador está preocupado é com seu patrimônio e não com a vida ou segurança dos empregados.

Ao contrário do que pode parecer, não se defende a idéia de que o patrimônio do empregador deva ficar desprotegido. $\mathrm{O}$ direito ao patrimônio é defendido em lei, contudo, o pretexto da defesa do patrimônio não pode ser utilizado para ferir a intimidade do empregado.

Por conta do cenário antes exposto, cada vez mais surgem na Justiça do Trabalho pedidos de indenização por danos morais decorrentes da revista íntima. Em decisão de caso em que a reclamante dizia ser submetida cotidianamente a revista íntima, nas quais era demandado abaixar as calças até os joelhos e levantar a camisa até os ombros, o Tribunal Superior do Trabalho decidiu que "o poder fiscalizatório do empregador de proceder a revista íntima encontra limitação na garantia de preservação da honra e intimidade da pessoa física do empregado, conforme preceitua o art. $5^{\circ}$, inciso X, da Constituição da República. A realização de revistas sem a observância dos limites impostos pela ordem jurídica acarreta ao empregador a obrigação de reparar, pecuniariamente, os danos morais causados.”23

Nesse aspecto, vale exemplificar outros meios lícitos para a defesa dos bens do empregador, quais sejam: detector de metais, câmeras de segurança, inventário patrimonial, alarmes, entre tantos outros. Sendo assim, não há necessidade em o empregador se utilizar de meios violadores da dignidade humana. A revista íntima costuma ser usada por se tratar de um meio fiscalizatório barato. Em uma época em que a lógica é cortar custos e otimizar o lucro, os empreendimentos comerciais não visam investir em tecnologia de vigilância, preferindo fazer uso de meios mais baratos e simples como a revista íntima.

A discussão sobre revista íntima chegou ao Supremo Tribunal Federal, que entendeu que se a revista é feita "com resguardo dos atributos 
da dignidade da pessoa, sem constrangimento, mas, de modo previamente divulgado e aprovado pelo empregado da empresa. Tal conduta, quando processada segundo os padrões éticos, com discrição, privacidade, respeito e preservado a essência dos valores morais do ser humano, não deve ser, só por si, chamada de afrontosa ou agressiva à dignidade humana"24.

Dessa forma, o Supremo Tribunal Federal entendeu que a revista íntima pode ser realizada se houver prévio consentimento do empregado e se respeitar os padrões éticos, não havendo nesses casos, ofensa aos incisos II, III, LVII e X do art. $5^{\circ}$ da Constituição Federal para dar margem a danos morais.

Não obstante, tais entendimentos, existem inúmeras decisões divergentes nos Tribunais Regionais do Trabalho, o que mostra o quanto o tema precisa ser ainda debatido. A utilização de expressões como respeito aos "padrões éticos" 25 e "observância dos limites impostos pela ordem jurídica"26, pelos tribunais superiores para estabelecer limites à revista íntima, não ajuda às instâncias inferiores a solucionarem o caso concreto com a devida segurança jurídica, permanecendo as inúmeras decisões divergentes para casos semelhantes.

O Tribunal Regional do Trabalho da $15^{\mathrm{a}}$ Região (Campinas-SP) em recente decisão entendeu que embora o empregador tenha o direito de resguardar seu patrimônio, não está autorizado a violar o direito à intimidade de seus empregados. "Restou caracterizada a agressão à dignidade humana da obreira, sendo invadida a sua intimidade, portanto, magoado direito de personalidade. Irrelevante se a revista era feita por homem ou mulher, sendo só o fato 'revista' já invasor da privacidade do

24 STF - AI 220459 AgR/ RJ- Rio De Janeiro Ag.Reg.No Agravo de Instrumento Relator: Min. Moreira Alves Julgamento: 28/09/1999 - Primeira

25 STF- AI 220459 AgR/ RJ- Rio De Janeiro Ag.Reg.No Agravo de Instrumento Relator: Min. Moreira Alves Julgamento: 28/09/1999 - Primeira Turm

26 TST - RR 1.565/2001-664-09-00.2 - $3^{\mathrm{a}}$ T. - Rel $^{\mathrm{a}}$ Min. Maria Cristina Irigoyen Peduzzi - DJU 20.08.2004. 
trabalhador, embora, bem é de ver, quando feita por varão, mais grave ainda", disse o relator, que foi acompanhado por unanimidade27.

Em seu julgado, o relator citou outras decisões no mesmo sentido que vale reproduzi-las:

De modo geral, o Direito confere à empregadora amplos poderes para adotar medidas visando a proteção do patrimônio da empresa, mas não a ponto de afrontar os comandos legais que resguardam a dignidade do ser humano; não se permite à dadora de serviços arvorar-se em poderes de polícia e -talvez mais ainda- ato contínuo infringir direitos básicos do cidadão, sob pretexto de haver a necessidade de resguardar o seu patrimônio e sua atividade.28

O direito à fiscalização patronal deve pautar-se no bom senso, métodos e meios razoáveis, não podendo, de modo algum, transbordar a ponto de expor os funcionários da empresa - cujo vínculo empregatício só tem sentido mediante o pressuposto da existência de confiança mútua -, a situações vexatórias e/ou constrangedoras, lembrando que a dignidade da pessoa humana configura imperativo axiológico do ordenamento jurídico do Estado Democrático de Direito, a teor do art. $1^{\circ}$, inciso III, da CF, como percucientemente anotado no v. acórdão n. 025965/2006-PATR, do processo n. 01847-2004-062-15-00-8-RO, relator Desembargador José Antonio Pancotti, publicado no DOE/SP em 09/06/2006, “in” sítio eletrônico do E. TRT-15.

REVISTA ÍNTIMA - COLISÃO DE PRINCÍPIOS FUNDAMENTAIS PREPONDERÂNCIA DOS VALORES FUNDAMENTAIS INERENTES À DIGINIDADE DA PESSOA HUMANA - INDENIZAÇÃO POR DANOS MORAIS - VIABILIDADE. A atividade econômica nas sociedades capitalistas, regidas por princípios do Estado de Direito Democrático e Social, não se nega ao empresário o soberano poder de organização, direção e controle de sua atividade. Tais poderes encontram fundamento na garantia constitucional da liberdade de iniciativa, da livre de concorrência (CF/88, art., $1^{\circ}$, IV, $3^{\circ}$, II, 5ㅇ, XXII e 173), como valores essenciais não só ao desenvolvimento econômico, mas, sobretudo, para a criação e manutenção de postos de trabalho e criar ambiente para inclusão social. São, ainda, instrumentos que visam obter melhor qualidade e maior produtividade de bens ou serviços, a disciplina e harmonia no ambiente de trabalho e zelo pelo patrimônio da empresa. O exercício destes poderes pelo empresário não pode, porém, acarretar a privação ou a diminuição de bens e valores fundamentais à dignidade da pessoa humana, ou de valores fundamentais inerentes à personalidade do cidadão trabalhador, reconhecidos como relevantes, pela sociedade na qual está integrado - que são igualmente tutelados pela ordem constitucional (CF/88, art. $1^{\circ}, I I I, I V, 3^{\circ}, I, 5^{\circ}, X$ e $\left.7^{\circ}, X X X\right)$. Na dinâmica da atividade econômica, soe acontecer que o empregador, ainda que de boa fé, acabe tendo conduta que colide com os direitos fundamentais do cidadão. Na hipótese, a conduta patronal, em conseqüência das revistas íntimas a que foi submetida a reclamante, inclusive por pessoa do sexo oposto, em que funcionárias eram tocadas ou apalpadas em seus corpos, ficou patente a

${ }_{27}$ TRT - $15^{\mathrm{a}}$ Região - RO - RECURSO ORDINÁRIO - Proc. nº. 0232-2008-022-15-00-9 Campinas - SP - $5^{\text {a }}$ Câmara (Terceira Turma) - Data: 12/08/2008. 
agressão à sua intimidade, fazendo jus a uma indenização reparadora e que venha inibir, no futuro, a conduta ilícita da empregadora. A cidadão trabalhadora tem direito de receber tratamento digno dentro e fora do ambiente de trabalho.

Recurso ordinário da reclamada a que se nega provimento, no particular.29

Desse modo, vê-se que alguns juristas entendem que há violação à intimidade e à honra qualquer tipo de revista íntima, mas outros dizem que dentro de alguns limites éticos a revista poder ser feita, não acarretando danos morais.

Ao fazer uma pesquisa conjunta em todos os Tribunais Regionais do Trabalho podemos constatar que as divergências são inúmeras e que as mais diversas teses são adotadas como fundamentação. Assim, ao mesmo tempo em que temos decisões inadmitindo qualquer tipo de revista íntima ou a pertences, temos decisões que consideram legal a revista íntima ou à pertences sob o fundamento de que faz parte do poder fiscalizatório do empregador, e ainda decisões que adotam o meio termo, alegando ser possível a revista íntima se respeitados os padrões e limites, que são indefinidos.

O método da ponderação de direitos/interesses é utilizado em muitas decisões para solucionar o caso concreto, prevalecendo ora o direito à intimidade ora o poder diretivo. Nesses termos, se baseando no princípio da dignidade da pessoa humana, a grande maioria das decisões vem garantido o direito à intimidade em detrimento ao poder diretivo do empregador, visto que o constrangimento está presente em qualquer tipo de revista íntima, sendo assim, passa-se a transcrever algumas dessas decisões:

REVISTA ÍNTIMA - DANO MORAL - O empregador como titular do poder diretivo tem como prerrogativa, além de traçar metas para que seus objetivos sejam atingidos, o de tomar medidas para salvaguardar seu patrimônio. Não obstante tal premissa há de ser em primeiro lugar e sobre qualquer outro direito fundamental, salvaguardada a dignidade da pessoa do trabalhador em relação aos métodos que porventura sejam utilizados pelo empregador para garantir a integridade de seu patrimônio. Isso porque a prerrogativa de proteção do patrimônio não se sobrepõe, jamais, ao princípio da dignidade humana (valor

29 Acórdão n. 039419/2006-PATR, processo n. 00181-2005-087-15-00-8-RO, publicado DOE/SP em 25/08/2006, “in” sítio eletrônico do E. TRT-15 - grifei. 
humano), encontrando limite intransponível nos direitos personalíssimos. A revista de empregado é conduta invasiva da privacidade, viola a intimidade, a vida privada, a honra e a imagem do trabalhador, direitos estes assegurados por norma constitucional - art. $5^{\circ}$, X da CF/88 - configurando procedimento vexatório e

humilhante que impõe a correspondente indenização por danos morais - art. $5^{\circ}, \mathrm{V}$, CF/88.30

TRT-PR-23-01-2009 DANO MORAL. REVISTA ÍNTIMA. O contrato de trabalho fundamenta-se na confiança e na boa-fé dos contratantes, de modo que eventuais dúvidas quanto à idoneidade do empregado não autorizam o empregador, a seu talante, submetê-lo a situações constrangedoras, porquanto a ação de fiscalizar, inserida no poder de controle, não pode se sobrepor à dignidade da pessoa do trabalhador. A revista íntima realizada pela ré fere os princípios da presunção de inocência e da dignidade do trabalhador, cabendo ao empregador, que, pelas condições em que o trabalho é realizado, corra o risco de sofrer furtos, investir em outros meios para proteger o seu patrimônio, já que a ele cabe os riscos da atividade econômica. Recurso a que se nega provimento.31

Vale ainda ressaltar, que algumas decisões impedem a revista íntima sob o fundamento de que a intimidade da pessoa humana, principalmente, hoje em dia é inviolável, visto que o avanço tecnológico atual permite a utilização de outros mecanismos para a proteção do patrimônio do empregador, verbis:

TROCA DE ROUPAS NA PRESENÇA DE FUNCIONÁRIO DA EMPRESA. CARACTERIZAÇÃO DA REVISTA ÍNTIMA. DANO MORAL. Obrigando a empresa seus funcionários a retirarem o uniforme em uma sala e passarem de roupa íntima para outro compartimento, onde deveriam colocar suas roupas na presença de funcionário da empresa, resta configurada a repudiada revista íntima, uma vez que esse comportamento expõe o corpo dos empregados, com violação ao artigo 5o, inciso X, da Constituição Federal vigente, que assegura, expressamente, a inviolabilidade da intimidade da pessoa humana, com a conseqüente indenização pelo dano moral decorrente desse tipo de lesão. Vale ressaltar que a empresa poderia utilizar-se de outros mecanismos de vigilância, tais como detectores de metal e câmeras filmadoras fixadas em áreas comuns, entretanto ela preferiu afrontar a dignidade de seus trabalhadores com a revista imprópria. Sentença reformada para deferir a indenização por danos morais.32

EMENTA: INDENIZAČ̃̃O POR DANO MORAL - CONFIGURAÇÃO REVISTA ÍNTIMA - VIOLAÇÃO À INTIMIDADE E PRIVACIDADE. A revista diária efetuada em empregado portando apenas roupa íntima, implica constrangimento e é abusiva, configurando dano moral indenizável,

principalmente porque já havia equipamentos capazes de substituí-la, como o

30 TRT2 Acórdão nº: 20090467315 Processo nº 02986-2005-037-02-00-0; Relator(A): Ivani Contini Bramante; $4^{\text {a }}$ Turma; Data de Publicação: 19/06/2009 - grifei.

31 TRT9-PR-00164-2006-089-09-00-7-ACO-01159-2009 - 1A. TURMA - Relator: CELIO HORST

WALDRAFF - Publicado no DJPR em 23-01-2009 - grifei.

32 TRT18 Processo 01013-2008-004-18-00-9 Relator(A) :ELZA CÂNDIDA DA SILVEIRA -

Primeira Turma - grifei. 
detector de objetos posteriormente implantado pela empresa. O poder de fiscalização da empregadora deve ser exercido de acordo com os direitos fundamentais, preservando a dignidade da pessoa humana.33

Dano moral. Revista íntima. Configuração. O empregador, no exercício do poder de fiscalização tem o direito de adotar medidas com vistas a proteger o patrimônio empresarial. No entanto, esse poder não pode transbordar o dever indeclinável de respeito à dignidade da pessoa do trabalhador. A revista íntima do empregado, obrigando-o a despir suas vestes, ainda que de forma parcial, é uma maneira de subjugar o trabalhador, colocando-o em situação de investigado. Há outros meios dos quais pode se valer o empresário para exercer permanente fiscalização de seu patrimônio, e a forma menos onerosa de exercê-la é a revista do trabalhador. Trata-se de conduta que agride a dignidade do laborista, ao ter que, rotineiramente, demonstrar que é honesto, a despeito do princípio da boa-fé das partes contratantes que rege, indistintamente, a execução de qualquer contrato. $\mathrm{O}$ valor da indenização deve se prestar a reparar o dano sofrido como, igualmente, possuir finalidade pedagógica, no sentido de desestimular a perpetuação desse tipo de conduta empresarial de habitualmente por em xeque a honestidade do trabalhador, fato que objetivamente é motivo de angústia e frustração, suportadas pela necessidade do trabalho para prover o sustento próprio e da família.34

O acórdão transcrito acima ressalta uma realidade brasileira, a de que a revista íntima é utilizada por muitas empresas atualmente, principalmente, por ser o método mais barato de fiscalização. Tal prática deve ser combatida pelo poder judiciário, visto que, por existirem outros meios de vigilância, não há razão para a violação do direito à intimidade, garantido pelo princípio da dignidade humana.

Não obstante as inúmeras decisões já citadas contrárias à revista íntima, existe ainda quem entenda que a aquela compõe o poder fiscalizatório do empregador. Tal entendimento faz com que casos semelhantes sejam julgados de forma distinta por turmas que integram o mesmo Tribunal Regional do Trabalho, como exemplo podemos mencionar a Segunda Turma e a Primeira Turma do Tribunal Regional Federal da $5^{\text {a }}$ Região.

Ementa: DANO MORAL. REVISTA ÍNTIMA. O mero procedimento de revista do empregado, realizado como expressão do poder diretivo do empregador, sem

33 TRT3 -01297-2008-038-03-00-2-RO; Relator: Heriberto de Castro; Órgão Julgador: Turma Recursal de Juiz de Fora; Data da Publicação: 15/04/2009 - grifei.

34 TRT2 Acórdão nº: 20090339708 Processo nº: 00197-2007-383-02-00-2 Turma: 2ª; Relator: Rosa Maria Zuccaro; Data de Publicação:19/05/2009 - grifei. 
cometimento de qualquer excesso e sem submetê-lo a situação vexatória ou degradante, por si só, não configura ofensa à honra, permanecendo com o Obreiro o ônus de fazer prova do dano efetivamente sofrido. 35

Ementa: DANO MORAL. REVISTA ÍNTIMA. DIGNIDADE DO SER

HUMANO. A revista efetivada, seja em pertences, ou no próprio empregado, de forma pessoal, já caracteriza violação da intimidade, configurando o dano de ordem moral, sendo a indenização seu corolário, na responsabilidade civil afeita ao empregador, ante a ilicitude do ato perpetrado, preservando-se o princípio constitucional da dignidade do ser humano, que não se admite colida com o direito de preservação da propriedade. Nesse passo, "a pessoa tanto pode ser lesada no que tem, como no que é. E que se tenha um direito à liberdade ninguém o pode contestar, como contestar não se pode, ainda, que se tenha um direito a sentimentos afetivos, a ninguém se recusa o direito à vida, à honra, à dignidade, a tudo isso enfim, que, sem possuir valor de troca da economia política, nem por isso deixa de constituir um bem valioso para a humanidade inteira. São direitos que decorrem da própria personalidade humana. São emanações diretas do eu de cada qual, verdadeiros imperativos categóricos da existência humana" (Rudolf Von Ihering). 36

Por todo o já exposto, pode-se constatar que apesar de algumas divergências ainda existentes, majoritariamente tem-se entendido que a revista íntima rotineira deve ser inadmissível, não sendo método aceitável para a vigilância do patrimônio do empregador. Todavia, em casos excepcionais, como em suspeita de crime ou em função da atividade exercida pela empresa, o tema é debatido com maior vigor, havendo mais desavenças.

Ementa: DANO MORAL. REVISTA ÍNTIMA. Em se tratando, a reclamada, de um supermercado de grande porte, que pratica a revista com a finalidade de resguardar seu patrimônio, ante a facilidade com que podem ser desviados os produtos que comercia, contudo, sem restar provado que o fizesse acintosamente, de molde a incriminar quem quer que seja ou ferir a intimidade do seu empregado, não resta configurado o dano moral.37

EMENTA: REVISTA ÍNTIMA - ART. 5, X, DA CONSTITUIÇÃO DA

REPÚBLICA. A revista, em si, é procedimento legal, máxime em se tratando de atividade empresarial farmacêutica, amplamente regulamentada exatamente pelo fato de oferecer riscos à saúde humana. No entanto, a exposição do trabalhador a constrangimento é o limite do exercício do direito, ante o que dispõe o art. $5^{\circ}, \mathrm{X}$, da Constituição da República. A submissão dos empregados a passagem de um cômodo para outro, semidespidos, caracteriza revista íntima, ainda que sem sujeição a contato físico. Trata-se de exposição do corpo, inerente à

35 TRT5 Processo 01060-2007-464-05-00-9 RecOrd, ac. nº 022370/2009, Relatora Desembargadora ELISA AMADO, $1^{\text {a }}$. TURMA, DJ 09/09/2009 - grifei.

36 TRT5 Processo 01231-2008-021-05-00-0 RecOrd, ac. nº 019032/2009, Relatora Juiza

Convocada MARGARETH RODRIGUES COSTA, $2^{\mathrm{a}}$. TURMA, DJ 18/08/2009 - grifei.

37 TRT5 Processo 01141-2008-013-05-00-4 RecOrd, ac. $n^{\circ}$ 018672/2009, Relatora

Desembargadora MARAMA CARNEIRO, $1^{\mathrm{a}}$. TURMA, DJ 12/08/2009 - grifei. 
personalidade humana, não só à pessoa responsável pela revista, mas também aos colegas de trabalho.38

Ementa: DANO MORAL INDEFERIDO - a revista íntima desde quando não atinge a dignidade do trabalhador é permitida, especialmente quando a empregadora tem por atividade a custódia de menores infratores e a medida, de segurança, visa evitar trânsito de armas e drogas.39

Nesse sentido, cabe ressaltar, que o acórdão fundamenta a sua decisão no fato de que "a revista ainda que íntima era realizada nos moldes descritos na defesa, em sala fechada, acompanhada por um colega, além do funcionário que a procedia, como medida em benefício da comunidade que se destinava á reeducação de menores infratores.Por outro lado, a simples presença do detector de metais não impediria a entrada de drogas, tão criativo o transporte vem se mostrando, como bem salientou o juízo de origem”.

EMENTA: INDENIZAÇÃO POR DANOS MORAIS. REVISTA ÍNTIMA " É aceitável e até, infelizmente, necessária, a revista íntima de empregados que manuseiam diariamente grandes quantias de dinheiro, posto que esse procedimento desafie a dignidade humana que, em muitos casos, não resiste a tal espécie de tentação. O que não se pode aceitar, contudo, é a colocação de dois colegas de trabalho nus, lado a lado, para que eles sejam "vistoriados" por vários vigilantes que se revezam ao longo da semana e, ainda por cima, fazem brincadeiras sobre suas características físicas. Dessa maneira, chegamos à situação de uma "revista coletiva", que não pode ser tolerada já que não estamos lidando com gado, mas com seres humanos.40

E M E N T A: DANOS MORAIS. REVISTA ÍNTIMA CONSTRAN-GEDORA. VIOLAÇÃO DO DIREITO À HONRA DA EMPREGADA. INDENIZAÇÃO DEVIDA. 1 - A prova carreada aos autos evidencia que a autora, além de ter sido constrangida ilegalmente a assinar uma nota promissória, foi submetida à realização de uma revista íntima, vexatória e desnecessária, sem que houvesse prova inequívoca do cometimento do prejuízo financeiro que lhe foi atribuído pela reclamada. 2 - Ao assim proceder, a empregadora incorreu em transgressão ao direito à honra, avultando inafastável a decisão do Juízo de primeiro grau que reconheceu a rescisão indireta do contrato de trabalho e deferiu a indenização por danos morais requerida pela empregada. 3 - Contudo, em se constatando que o valor atribuído na sentença à reparação pelo prejuízo moral se mostra excessivo, impõe-se reduzi-lo a um patamar justo, mas com expressão monetária o bastante

38 TRT3 Processo no 01415-2008-035-03-00-3 RO; Relator: Convocado Paulo Maurício Ribeiro Pires; Órgão Julgador: Turma Recursal de Juiz de Fora; Data da Publicação: 17/06/2009 - grifei. 39 TRT5 Processo 01258-2008-027-05-00-0 RecOrd, ac. nº 020883/2009, Redatora

Desembargadora YARA TRINDADE, $3^{\mathrm{a}}$. TURMA, DJ 02/09/2009 - grifei.

40 TRT3 Processo no 01328-2005-013-03-00-6-RO; Relator: Cleube de Freitas Pereira; Órgão Julgador: Oitava Turma; Data da Publicação: 06/05/2006 - grifei. 
para minorar o sofrimento da reclamante e incutir na re-clamada o respeito aos valores e princípios inerentes ao Direito do Trabalho. 4 - Recurso parcialmente provido.41

EMENTA: DANO MORAL - REVISTA ÍNTIMA PRECEDIDA DE ACUSÃÇÃO DE FURTO - NECESSIDADE DE PROVA CABAL. O respeito à

dignidade da pessoa humana constitui um dos fundamentos da Constituição da República, devendo tal fundamento ser garantido em todos os cidadãos nos diversos segmentos da sociedade. Deste modo, não se pode admitir que, em nome do poder diretivo e fiscalizador que a lei confere ao empregador e da subordinação decorrente da relação de emprego, venha o patrão submeter de forma impulsiva apenas um de seus empregados à revista íntima, precedida de acusação de furto, cuja autoria e materialidade do delito sequer restou comprovada. A imputação de ato de tamanha gravidade exige prova compacta, concreta e irretorquível, não podendo ser realizada de maneira leviana, considerando que a atribuição de desonesto ao empregado gera conseqüências que produzem efeitos negativos não apenas em sua órbita subjetiva, mas também em sua vida profissional, familiar e social. Destarte, constatada nos autos a ocorrência de tal hipótese, cabível a condenação do reclamado à indenização pelos danos morais sofridos pela reclamante, acusada de furto sem qualquer respaldo probatório.42

De acordo com as jurisprudências é possível perceber que em alguns casos excepcionais se admite a revista íntima, porém essa deve ser realizada de acordo com a razoabilidade e proporcionalidade, ponderação feita pelos órgãos julgadores. Assim, percebe-se que até mesmo nesses casos são impostos limites à revista íntima, a qual não pode ser realizada coletivamente, por pessoas de sexo oposto, em ambiente aberto e com contato físico.

Com relação a essas jurisprudências que admitiram a revista íntima em casos de suspeita de furto dentro da empresa, vale mencionar o sábio entendimento de Sandra Lia Simón:

\section{(...)}

Nesse sentido, é possível afirmar que a prática da revista desrespeita o princípio da presunção de inocência, inculpido no art. $5^{\circ}$, inciso LVII. Ademais, se aos acusados são assegurados o contraditório e a ampla defesa, nos termos do art. $5^{\circ}$, inciso LV, como excluir da incidência desse dispositivo os simples "suspeitos" ? Da mesma forma, o princípio da igualdade (art. 5, caput) é flagrantemente desrespeitado. Privilegia-se o empregador, autorizando-o a tomar medida para

41 TRT13 Ro88964 Recurso Ordinário 01522.2005.022.13.00-8; Relator: FRANCISCO DE ASSIS CARVALHO E SILVA; Órgão Julgador: Tribunal Pleno; Data da Publicação: 26/07/2006 - grifei.

42 TRT3 00012-2008-144-03-00-6-RO; Relator: Convocada Maristela Iris da Silva Malheiros; Órgão Julgador: Segunda Turma; Data da Publicação: 27/08/2008 - grifei. 
defesa de seu patrimônio que nenhuma outra pessoa pode adotar, e prejudica-se o empregado, pelo simples fato de encontrar-se numa relação de subordinação. Retira-se, ainda, do Estado a exclusividade da função policial, que tem por objetivo preservar o bem "segurança Pública” (art.144). O "poder de revistar” é típica função da polícia e, se é exercido pelo empregador, assume característica de "polícia privada”.

(...)43

A despeito do ramo empresarial a que se dedica a empresa, que lida, por exemplo, com drogas farmacológicas poderosas ou grande volume de dinheiro, o que lhe autoriza proceder a uma fiscalização mais rigorosa, o procedimento encontra limites no direito de intimidade de seus empregados. Cumpre ressaltar que o poder diretivo conferido ao empregador encontra-se fundamentado em lei, onde também residem seus marcos delimitadores.

Portanto, a exposição parcial/total do corpo do trabalhador, invade sua intimidade, e só seria permitida em casos graves e com severas restrições. Nesse sentido, preleciona a Professora Alice Monteiro de Barros:

Revista que pressupõe inspeção direta sobre o corpo do empregado. Exigência de que o empregado se desnude. Violação ao direito à intimidade.

Outro aspecto diz respeito à revista que pressupõe inspeção direta sobre o corpo

do empregado suspeito de furto de pequenos objetos de grande valor (jóias, pedras preciosas).

Com razão está a doutrina estrangeira quando assevera que a inspeção nessas condições poderá traduzir atentado contra o pudor natural da pessoa, dependendo da intensidade do exame. Portanto, considera-se atentatória à intimidade a inspeção que exige que o indivíduo se desnude completamente, ainda que perante pessoas do mesmo sexo, e se submeta a exame minucioso, detalhado, prolongado ou em presença de outros. A revista nessas condições encontra limite no respeito à dignidade do trabalhador.

Neste sentido nos pronunciamos como relatora do processo RO-313/97, que tramitou perante a $2^{\text {a }}$ Turma do TRT da $3^{\text {a }}$ Região, cuja ementa é a seguinte: REVISTA. DESRESPEITO À INTIMIDADE DO TRABALHADOR. DANO MORAL. A circunstância de a empresa trabalhar com drogas valiosas, muito visadas pelo comércio ilegal ,justifica a utilização de fiscalização rigorosa, inclusive a revista, até porque o empregador está obrigado a zelar para que esses medicamentos não sejam objeto de tráfico ilícito, evitando a sua comercialização indiscriminada. Sucede que a revista deverá ser admitida como último recurso para defender o patrimônio empresarial e salvaguardar a segurança dentro da empresa, à falta de outras medidas preventivas; mesmo assim, quando utilizada, deverá respeitar a dignidade do trabalhador, evitando ferir-lhe o direito à intimidade. Se a revista implica no fato de o empregado desnudar-se completamente e ainda ter que caminhar por pequeno percurso, a fiscalização atenta contra o direito à intimidade do empregado e autoriza o pagamento de 
indenização por dano moral (art. 5 X da Constituição da República/1988, no título “Dos Direitos e Garantias Fundamentais”). Ora, „numa época em que os imperativos econômicos do mercado questionam os dogmas tradicionais " do Direito do Trabalho, inclusive o princípio da proteção, o vigor dos direitos fundamentais dos trabalhadores nas empresas poderá traduzir „um antídoto para emancipar o contrato de trabalho " de sua excessiva subordinação à economia, permitindo que essa disciplina recupere seu papel de assegurar a auto-realização do empregado como cidadão.44

Um aspecto igualmente relevante e também muito discutido é com relação à vistoria feita a pertences dos empregados, o que é visto como um abuso ao poder diretivo do empregador e uma violação à intimidade por alguns tribunais e por outros como um tipo de revista possível, se efetuada com os devidos cuidados.

Ementa: PROCEDIMENTO DE REVISTA (NÃO-INTIMA). LEGALIDADE. REQUISITOS. A realização de revistas (não-íntimas) está inserida no rol dos poderes diretivo e fiscalizador do empregador, com vistas ao resguardo do seu patrimônio. Entretanto, para que estas não incidam em ofensa aos direitos de liberdade, integridade, dignidade e proteção da honra e da imagem dos trabalhadores, hão de ser realizadas com os devidos cuidados. A partir do instante em que a revista é realizada na frente dos clientes, em ambiente aberto (nãoreservado), caracteriza-se o constrangimento para os empregados, constituindo-se o excesso punível e o dano moral.45

REVISTA ROTINEIRA NA BOLSA E SACOLAS DE FUNCIONÁRIOS. HORÁRIO DE SAÍDA DO TRABALHO. LOCAL RESERVADO. CARÁTER NÃO ABUSIVO NEM VEXATÓRIO. AUSÊNCIA DE OFENSA À HONRA E DIGNIDADE DA PESSOA. DANO MORAL. INOCORRÊNCIA. A revista rotineira de bolsas e sacolas do pessoal da empresa, no horário de entrada e saída do serviço, constitui procedimento legítimo a ser utilizado pelo empregador como meio de proteção de seu patrimônio, ou como forma de tutela de sua integridade física e de seus empregados. Efetivamente, a maneira como realizada a revista, é que definirá a ocorrência ou não de dano moral. Nesse contexto, somente enseja o pagamento de indenização por dano moral, a revista em que o empregador extrapola o seu poder diretivo, mostrando-se abusiva, por constrange os empregados, colocando-os em situações de ultrajante, em frontal desrespeito à honra e à intimidade da pessoa humana. Na hipótese dos autos, segundo o quadro fático definido pelo Regional, não se pode considerar abusiva, nem vexatória, a revista, não ensejando, portanto, a condenação a indenização por dano moral, já que a revista foi realizada mediante o exame de sacolas e bolsas ao final do expediente, sem que o segurança sequer tocasse no empregado. Recurso de revista conhecido e provido.46

44 BARROS, Alice Monteiro. Curso de Direito do Trabalho, $5^{a}$ Edição, 2009, pág. 591/592

45 TRT5 Processo 01010-2006-038-05-00-1 RecOrd, ac. nº 023019/2009, Relator Desembargador ROBERTO PESSOA, $4^{\text {a }}$. TURMA, DJ 17/09/2009 - grifei.

46 TRT9 RR-250/2001-661-09-00.9). (Ver acórdão nº 00636-2006-101-04-00-8 RO, Rel. Desa Maria Beatriz Condessa Ferreira, publicado em 04.08.2008 - grifei. 
E M E N T A: AÇÃO CIVIL PÚBLICA. REVISTA EM OBJETOS PESSOAIS DOS EMPREGADOS NO INÍCIO E TÉRMINO DO EXPEDIENTE.

SUPERMERCADO. CONDUTA LESIVA À DIGNIDADE DO TRABALHA-

DOR. I - Ação Civil Pública ajuizada pelo Ministério Público do Trabalho, na qual avulta incontroverso o fato de que a reclamada, empresa ligada ao ramo comercial de supermercados, empreende sistematicamente a revista nos pertences de seus empregados no início e término do expediente, sob o pretexto de promover a segurança e de proteger seu patrimônio contra investidas criminosas. II - Tal conduta é antijurídica, pois, além de constituir abuso do poder diretivo empresarial, atenta contra o princípio da presunção da inocência, configurando ofensa à dignidade do trabalhador. III - Há de se ressaltar que, no ordenamento jurídico brasileiro, a intimidade do empregado - cujo conceito se estende aos seus objetos pessoais - constitui garantia inviolável, não podendo ser sobrepujada pelo direito de propriedade do empregador, sob pena de subversão dos valores jurídicos estabelecidos na Lei Maior. IV - Diante de tais considerações, é de ser confirmada a decisão de primeira instância quanto às obrigações de não fazer impostas à ré, no sentido de abster-se de realizar as referidas inspeções. V -

Entrementes, no caso específico dos autos, não há como concluir que a postura da empresa seja causadora de um sentimento social de indignação, de desagrado e de vergonha capaz de propiciar a indenização por dano moral coletivo em favor do Fundo de Amparo ao Trabalhador, razão pela qual se impõe excluir tal verba da condenação. VI - Recurso parcialmente provido.47

Após uma leitura atenta de todas as decisões transcritas, pode-se verificar que, mesmo naquelas em que se admite a revista íntima, existem limitações para a realização da mesma. É verdade que os parâmetros usados possuem conceito abrangente e indeterminado, mas as limitações estão presentes, 0 que mostra que o poder diretivo do empregador está limitado ante à intimidade de seus funcionários.

O argumento utilizado pelos defensores da revista íntima ou a pertences consiste no fato de que é ínsito ao poder diretivo a possibilidade de fiscalizar os seus funcionários, assim, o que determina a licitude ou não da revista é a forma mediante a qual a mesma é realizada. O fundamento dessa tese está no art. 187 do CC, verbis:

Art. 187. Também comete ato ilícito o titular de um direito que, ao exercê-lo, excede manifestamente os limites impostos pelo seu fim econômico ou social, pela boa-fé ou pelos bons costumes. 48 
Ocorre que, a referida tese não atenta para o fato de que a própria feitura da revista íntima, mesmo que realizada da maneira menos atentatória à privacidade e intimidade do empregado, já é uma conduta que excede manifestamente o direito diretivo do empregador, visto que atualmente existem outros métodos de vigilância, apesar de serem mais onerosos.

Por fim, cumpre lembrar, que a liberdade da empresa supõe o poder de decisão do empregador sobre a estrutura e funcionamento daquela, a disponibilidade sobre os meios de produção e a direção da prestação de trabalho do pessoal contratado de acordo com as condições pactuadas no contrato de trabalho. Porém um contrato de trabalho não pode ignorar os princípios da boa-fé e diligência profissional, visto que a autonomia organizativa do empresário não é ilimitada, devendo respeitar também os direitos reconhecidos pela constituição, principalmente aqueles baseados no princípio da dignidade da pessoa humana, alicerce basilar da Lei Magna.

Portanto, o direito à intimidade é um direito indisponível, que não pode ter sua violação contratualmente estipulada, já não há como renunciá-lo. Dessa forma, o empregador deveria ser o primeiro a resguardar os direitos constitucionais de seus funcionários, visando manter o ambiente de trabalho sem qualquer tipo de invasão na esfera reservada da personalidade humana com a imposição de condições vexatórias que extrapolam os limites do poder de direção, disciplina e fiscalização dos serviços prestados. Nesse mesmo sentido, entendeu a quarta turma do Tribunal Regional do Trabalho ao decidir que "a revista íntima não pode ser vista como regra ou condição contratual, pois nem mesmo a autoridade policial está autorizada a proceder dessa forma sem mandado.”.49 
A "palavra-chave” para todo o exposto neste trabalho é equilíbrio, ou seja, o direito deve ser aplicado de modo proporcional em virtude da falta de legitimação específica existente e a necessidade de se fazer uso das normas gerais que não vislumbram de forma clara as limitações existentes, por exemplo, no direito à intimidade.

Sob a ótica legal, não há possibilidade de revista, salvo em casos excepcionais ("sui generis") que possua previsão normativa em lei (que deve surgir para regular e especificar tais exceções), não sendo possível a previsão em acordo ou convenção coletiva.

Os casos de revista íntima julgados pelos tribunais envolvem, predominantemente, empresas de vestuário e de medicamentos, de vigilância bancária e transporte de valores. O Tribunal Superior do Trabalho vem considerando o procedimento, adotado geralmente para inibir furtos, uma ofensa à honra, à dignidade e à intimidade do empregado.

A opção da minoria da doutrina e da jurisprudência em tolerar a realização de revistas, como expressão do poder de direção do empregador, ainda que com observância de alguns requisitos, não foi feita com base no juízo de ponderação que norteia a solução das colisões de direitos.

A condenação dessas empresas significa uma evolução, não apenas do direito em si, mas também do cidadão que não tem aceitado humilhação e desrespeito com o seu corpo e sua vida privada por parte do empregador. Além do constrangimento moral e social, há um dano psicológico. A prática é lesiva e existem inúmeras formas, com ajuda tecnológica, de observar e controlar os empregados e proteger os bens do empregador.

Diante dos argumentos expostos na presente pesquisa, resta demonstrada a inadmissibilidade da revista íntima como método de fiscalização dos funcionários pelos empregadores, posto que se deve preservar ao máximo o princípio da dignidade humana. 
Como foi evidenciado, a revista íntima deve se constituir o último recurso de segurança utilizado pelo empregador. A utilização dos avançados meios tecnológicos, tais como colocação de etiquetas magnéticas em livros, roupas e remédios; uso de senhas; controle na entrada e saída do estoque e da linha de produção; filmagens por circuito interno; detector de metais afixado no chão ou manual; ou até mesmo vigilância feita por serviço especializado ou de chapelarias para os funcionários podem dispensar a revista.

Cabe lembrar, no entanto, que os recursos tecnológicos devem ser utilizados com cautela, pois o uso indiscriminado de câmaras filmadoras em banheiros ou vestuários, por exemplo, pode gerar indenização por danos morais.

Definir o que não é constrangedor é muito difícil, já que cada pessoa tem uma visão diferente da própria intimidade, estando ligada às características pessoas. Em caso de submissão à revista, o empregado deve recusar-se e, nesse caso, é necessária a presença de testemunhas e que se verifique se outras formas de fiscalização foram utilizadas antes da revista íntima. No entanto, na prática se sabe que, na grande maioria dos casos, os trabalhadores se submetem a qualquer tipo de constrangimento para não perder o emprego. Essa realidade brasileira precisa mudar.

Nesse sentido, uma proteção constitucional mais rigorosa e eficaz se faz necessária, pois o homem moderno só conseguirá desenvolver sua personalidade através do reconhecimento do direito à intimidade, como direito fundamental. Trata-se de um direito essencial à dignidade humana e sua importância é indiscutível no atual regime democrático. Para que a liberdade individual exista é preciso o reconhecimento da intimidade como um direito.50

Em nada adianta o Estado respeitar o direito à intimidade e à vida privada dos indivíduos, se não houver mecanismos que imponham esse 
mesmo dever aos empresários, no âmbito das relações laborais, bem como ao particular e à sociedade como um todo.

Logo, segundo Sandra Lia Simón “ainda que haja um centro consolidado de poder, ainda que haja a constitucionalização das liberdades públicas, sem um verdadeiro sentimento constitucional, estas liberdades públicas não serão totalmente efetivadas.” ${ }_{51}$

Segurança e privacidade somam-se em vez de subtrair. Uma complementa a outra. O necessário é ter discernimento, é saber até onde e como se pode ir, observando-se os limites de cada um e suas interligações e ramificações, diretas e ou indiretas. 


\section{BIBLIOGRAFIA}

AIETA, Vania Siciliano. A Garantia da Intimidade como Direito Fundamental. Rio de Janeiro: Editora Lumen Júris, 1999.

BARCELLOS, Ana Paula. Alguns Parâmetros Normativos para a Ponderação Constitucional, in: Luis Roberto Barroso (Org.), A NOVA INTERPRETAÇÃO CONSTITUCIONAL. PONDERAÇÃO, DIREITOS FUNDAMENTAIS E RELAÇÕES PRIVADAS. Rio de Janeiro: Renovar, 2003.

BARROS, Alice Monteiro de. Curso de Direito Do Trabalho, LTr Editora, 5 Edição, 2009.

BARROS, Alice Monteiro de. Proteção à Intimidade do Empregado. São Paulo: LTr, 1997.

BELMONTE, Alexandre Angra. Instituições Civis No Direito do Trabalho, $2^{\mathrm{a}}$ Ed., Renovar.

BRANCO, Ana Paula Tauceda. A Colisão de Princípios Constitucionais no Direito do Trabalho, Editora LTr, São Paulo, 2007.

BRAZ, C. C.. A Proteção da Intimidade e a Liberdade de Expressão. Revista Objetiva, 2006.

BONAVIDES, Paulo. Curso de Direito Constitucional, Malheiros Editores, 23 $3^{\mathrm{a}}$ Edição, 2008. 
DINIZ, Maria Helena. Curso de Direito Civil Brasileiro: Responsabilidade Civil, v.7, $4{ }^{\text {a }}$ Edição. São Paulo: Saraiva, 1988.

GOMES, Orlando. Introdução ao Direito Civil, 10 a Edição. Rio de Janeiro: Forense, 1994.

MAGANO, Octavio Bueno. Do Poder Diretivo na Empresa. São Paulo: Saraiva, 1982.

MAGANO, Octavio Bueno. Manual de Direito do Trabalho: Direito Individual do Trabalho, v.II, $2{ }^{\text {a }}$ Edição. São Paulo: LTr, 1984.

MARQUES, Andréa Neves Gonzaga. Direito à Intimidade e Privacidade, Revista Jus Vigilantibus, 23 de fevereiro de 2008.

MIRANDA, Francisco Cavalcanti Pontes de. Tratado de Direito Privado, 4 Ed., Revista dos Tribunais, 1983.

SARMENTO, Daniel. A Ponderação de Interesses na Constituição Federal. Editora Lumen Júris, 2002.

SILVA, José Afonso da. Curso de Direito Constitucional Positivo, $8^{\mathrm{a}}$ Ed.. São Paulo: Malheiros Editores, 1992.

SOUZA, Mauro Cesar Martins de. E-mail (... Net) na relação de emprego: poder diretivo do empregador (segurança) \& privacidade do empregado; Matéria publicada em 01/11/2000 - Edição Número 15 < www.kplus.com.br >. Acesso em 20-09-2009.

STF, AI n. 220459 AgR/ RJ- Rio De Janeiro Ag.Reg.No Agravo de Instrumento, Rel. Min. Moreira Alves, Brasília, 28 setembro 1999. 
TRT, $2^{a}$ Região, Acórdão n ${ }^{\circ}$. 20090467315, Processo n ${ }^{0}$. 02986-2005-03702-00-0, Rel. Ivani Contini Bramante, São Paulo, 19 junho 2009.

TRT, $2^{\text {a }}$ Região, Acórdão nº: 20090339708, Processo nº: 00197-2007-38302-00-2, Rel. Rosa Maria Zuccaro, São Paulo, 19 maio 2009.

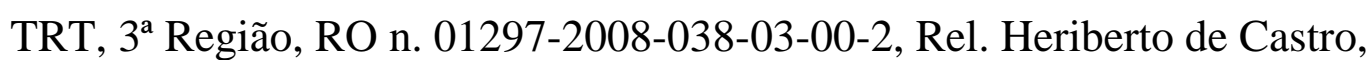
Minas Gerais, 15 abril 2009.

TRT, $3^{\text {a }}$ Região, RO n. 01415-2008-035-03-00-3, Rel. Convocado Paulo Maurício Ribeiro Pires, Minas Gerais, 17 junho 2009.

TRT, $3^{\text {a }}$ Região, RO n. 01328-2005-013-03-00-6, Rel. Cleube de Freitas Pereira, Minas Gerais, 06 maio 2006.

TRT, $3^{\text {a }}$ Região, RO n. 00012-2008-144-03-00-6, Rel. Convocada Maristela Iris da Silva Malheiros, Minas Gerais, 27 agosto 2008.

TRT, 5 a Região, RO n. 01060-2007-464-05-00-9, Rel. Desembargadora Elisa Amado, Bahia, 09 setembro 2009.

TRT, 5 a Região, RO n. 01231-2008-021-05-00-0, Rel. Juiza Convocada Margareth Rodrigues Costa, Bahia, 18 agosto 2009.

TRT, 5 a Região, RO n. 01141-2008-013-05-00-4, Rel. Desembargadora Marama Carneiro, Bahia, 12 agosto 2009.

TRT, 5 a Região, RO n. 01258-2008-027-05-00-0, Rel. Desembargadora Yara Trindade, Bahia, 02 setembro 2009. 
TRT, 5 a Região, RO n. 01010-2006-038-05-00-1, Rel. Desembargador Roberto Pessoa, Bahia, 17 setembro 2009.

TRT, $8^{a}$ Região, Acórdão nº 20090729000, Processo nº. 01126-2006-38302-00-6, Rel. Ricardo Artur Costa E Trigueiros, 18 setembro 2009.

TRT, 9a Região, PR-00164-2006-089-09-00-7-ACO-01159-2009, Rel. Celio Horst Waldraff, Paraná, 23 janeiro 2009.

TRT, $13^{a}$ Região, RO n. 01522.2005.022.13.00-8, Rel. Francisco de Assis Carvalho e Silva, Paraíba, 26 julho 2006.

TRT, $13^{\text {a }}$ Região, ROn. 01563.2005.006.13.00-5, Rel. Paulo Maia Filho, Paraíba, 20 julho 2006.

TRT, 15a Região, RO n. 00475-2004-126-15-007-7, Rel. Desembargador Lorival Ferreira dos Santos, São Paulo, 23 setembro 2005.

TRT, $15^{\circ}$ Região, RO n. 00181-2005-087-15-00-8, Rel. Juiz José Antonio Pancotti, São Paulo, 25 agosto 2006.

TRT, 18 ${ }^{\text {a }}$ Região, Proc. 01013-2008-004-18-00-9, Rel. Elza Cândida da Silveira, Goiás, 15 janeiro 2009.

TST, RR n. 1.565/2001-664-09-00.2, Rel ${ }^{a}$ Min. Maria Cristina Irigoyen Peduzzi, Brasília, 20 agosto 2004.

VÁLIO, Marcelo Roberto Bruno e TAVARES, Aline Aparecida da Silva. Do Princípio da Intimidade do Empregado X Poder Diretivo do Empregador, Revista Jus Vigilantibus, dia 08-05-2006. 